Review Article

\title{
Heterogeneous Phyto-Antibiotics and Other Future Therapeutics Against Multi-Drug Resistant Bacteria
}

\section{Asit Kumar Chakraborty}

Department of Biotechnology and Biochemistry, OIST, Vidyasagar University, Midnapore, India

\section{Email address:}

chakraakc@gmail.com

\section{To cite this article:}

Asit Kumar Chakraborty. Heterogeneous Phyto-Antibiotics and Other Future Therapeutics Against Multi-Drug Resistant Bacteria. Advances in Biochemistry. Vol. 7, No. 2, 2019, pp. 34-50. doi: 10.11648/j.ab.20190702.11

Received: June 27, 2019; Accepted: July 30, 2019; Published: August 23, 2019

\begin{abstract}
Phage therapy, enzybiotics, gene medicine and nanodrug-carriers are most vital components of modern research against multidrug-resistant bacteria. Genome evolution occurs due to environmental toxicities of various types where soil bacteria are in symbiosis with plant world who secret anti-metabolites against soil bacteria. Gut microbiome secrete vitamins required for our body where as intestinal cells synthesis interleukins and cytokines for symbiotic control of intestinal bacteria. Before the discovery of antibiotic in 1928, peoples trusted plant derived remedies against variety of illness described in Indian Sanskrit books like Charaka Samhita, Sasruta Samhita and Atharva Veda. AMR disease occurred due to repeated but uncontrolled use of antibiotics affecting gut microbiome who acquired many $m d r$ genes in plasmids. We estimated that $40 \%$ of all river and sea water borne bacteria were ampicillin and to lesser extent tetracycline, azithromycin, ciprofloxacin and streptomycin resistant. Where as $<1 \%$ were multidrug-resistant and $\sim 0.002 \%$ Enterobacteriaceae were meropenem, linezolid or amikacin resistant. MDR genes like amp, neo, tet, aac, cat, aph, aad, mcr-1, blaNDM-1, blaKPC-1, arr3, sul1, dhfr, inh, acrAB, mexAB, $m a c A B$ and $m \operatorname{tr} C D$ were amplified with millions mutated isomers increasing all drugs MIC. We studied Indian medicinal plants and spices to get valuable cheap drugs where modified agriculture and/or tissue culture increased the drug concentration. We showed that MDR bacteria were sensitive to organic extract of Suregada multiflora roots, Cassia fistula bark, Jatropha gossypifolia roots as well as Indian spices Labanga and Derchini (MDR-Cure). TLC and HPLC purification as well as UV-VIS, MASS, NMR, FT-IR and XRD-Powder gave many distinct signatures of pure chemicals that also inhibited multidrug-resistant bacteria. Biological targets of 12 chemicals are under investigation targeting DNA Topoisomerase I, DNA Polymerase and RNA Polymerase of Escherichia coli. Indian Government has started Herbal Mission, Ganga Mission and various Plantation Programmes to curve MDR pathogenesis.
\end{abstract}

Keywords: Multidrug-Resistance, Superbug Spread, Antibiotic Void, Drug Design, Heterogeneous Phyto-Antibiotics, Gut Biofilm, Vitamin Synthesis

\section{Introduction: History of Modern Medicine}

Human civilization suffers from different diseases caused by microorganisms those we cannot see by naked eyes [1]. Thus, since ancient times many medical orthodox prevails based on ghosts and demons, or Gods and Goddess, or physical forces like wind, rain and dort. Even Sun, River and Moon play a central role and plants are most worshiped for their utility, fruits and most importantly medicinal properties $[2,3]$. In India, Shitala Goddess is still worshiped in most villages of India as the cause of cholera even each student in the school now knows about Vibrio cholerae bacteria that causes cholera epidemic [4]. Thus, society needs to be properly educated to make vibrant and progressive. We now know bacteria, fungi, protozoa are unicellular but metabolism of carbohydrate food into glucose to pyruvic acid is very similar with human. Nucleic acids synthesis and protein synthesis chemical reactions involving thousand enzymes are also pretty similar although molecular assemblies (ribosome, mitochondria, DNA polymerase complex) are different and more complex so that antibiotics poorly inhibit human and animal central dogma processes (replication, transcription and 
translation). In truth, chemistry of bio-molecules and their enzymatic reaction mechanisms have unfolded very quickly since the discovery of structure of DNA in 1953 followed by DNA sequencing and recombinant DNA technologies. Interestingly, we knew antibiotics since 1928 but due to two World Wars, we got enough antibiotics for all in 1950s. The plants active principles (quinine, artiminisin, camptothecin, taxol) are now purified to use as drug and their mode of actions have elucidated performing in vitro and in vivo reaction kinetics [5]. We also synthesis DNA, protein, lipid, antibiotics and steroid hormones chemically in vitro $[6,7]$. We can engineer any gene to produce enough enzyme or antibiotic using bacteria or yeast plasmid expression vectors. Interestingly, using plant tissue culture we can make ex-metabolites or alkaloids or vitamins for human use. Still we suffer as cost of drugs and enzymes are high due to patent infringe and drug void following multi-resistance. I will focus on ancient technology of herbal drugs which now has been astonishingly complicated due to use of virtual screening, crystallography, tissue culture, expression cloning, transgenic, LC-MASS, NMR, FT-IR and Ion-exchange Sephadex Gel Chromatography technologies [8]. My vision is to make a platform for drug discovery from medicinal plants of one's garden who needs it. It must be cheap and technology must be easy and available. Scientists should make therapeutic herbal drugs like MDR-Cure visible to common man. Each year million middle class families are dragged into nasty poverty line due to high cost of drug!

\subsection{Discovery of Microorganisms}

The existence of microbes were described until Anton Von Leeuwenhoek observed microorganism through his microscope in 1670s followed by eminent microbiological work by Louis Pasteur (1860s) and Robert Koch in the 1870s [1]. Rough estimate for bacteria (dry mass) in this Earth is $>350000$ million tonnes indicating 3000 times heavier than human community (105 million tonnes). Soil contains $\sim 50000000$ bacteria/gm indicating major source of bacteria and then all water bodies (sea, river, pond) in this Earth [9]. Each human gut has $2 \times 10^{12}-4 \times 10^{13}$ bacteria and intestinal biofilm has major role in energy metabolism and immune-modulation between human and bacteria [10-13]. Ganga River water contains $\sim 10^{4}$ bacteria/ml and almost half of such microbes are ampicillin resistant and to lesser extent tetracycline, chloramphenicol, streptomycin and ciprofloxacin resistant $[14,15]$.

The antibiotic principle was discovered in 1928 by Alexander Flaming but it took until 1946 for large scale production and supply of penicillin drug for people. So mass people were taken antibiotics after World War II and within last 60 years we eradicated gut microbiota so drastically that save your soul worked signalling from human and bacteria both to create $m d r$ genes many folds. It is unbelievable to thing that penicillin, streptomycin, tetracycline, chloramphenicol, refampicin, azithromycin, ciprofloxacin, cefotaxime, sulfamethoxazole, and trimethoprim drugs are not killing bacteria [5]! Bacteria are ubiquitous and have located in air dust, sea and river water, utensils, surgical instruments, books, trees and human body. So question arises when we kill those bacteria with repeated oral antibiotic intake, what happens for vitamin synthesis? The answer is, we take multivitamin capsule and also we also take probiotic capsules after each antibiotic dose [12]. Although study indicated that due to high cost, poor patients hardly do that creating a set of metabolic syndromes like diabetes, pressure, diarrhoea, tension and allergy. Even few scientists claim adverse use of repeated antibiotics may cause cancer and genetic disorder if taken during pregnancy. Most importantly antibiotics without vitamins and probiotics caused $m d r$ gene creation and drug void.

\subsection{Roles of Plant Extract Eliminating Old Diseases}

The Sanskrit books Charaka Samhita and Sashruta Samhita as well as Atharva Veda are $\sim 5000$ years old Indian civilization describing the great science how to use phyto-extracts against diseases [16]. British Emperor did translate the books into English and thus we lost tradition but such concepts were visualized by US Companies and they were converted into World Leader Pharmaceutical Companies holding most patents of drugs and medicinal enzymes today. How many years ago people used the plants as drugs? The answer is unknown but as long as the diseases are prominent in human. The oldest written evidence of medicinal plant's usage has been found on a Sumerian clay slab from Nagpur, India ( 5000 years old) describing 12 recipes for drug preparation from 250 various plants, including poppy, henbane, and mandrake plants [17]. The Chinese book on medicinal roots and grasses "Pen T'Sao," written by Emperor Shen Nung on 2500 BC, described 365 drugs, many of which are used today like cinnamon, camphor, podophyllum, ginseng and ephedra [29]. The holy Bible and the Jewish book the Talmud described many aromatic plants for the treatment such as myrtle and incense. In Homer's epics The Iliad and The Odysseys (800 BC) described 63 plant species from the Minoan, Mycenaean, and Egyptian Assyrian pharmacotherapy to cure diseases which sometime referred as epic characters as Lords of Medicine. Theophrastus (371-287 BC) founded botanical science with his books "De Causis Plantarium"-Plant Etiology and "De Historia Plantarium"-Plant History describing cardamon, monkshood, hellebore, mint and cinnamon. Interestingly, Indian spices are great medicine and we will describe later how we have included organic Derchini (Cinnamon) and Labanga (Cloves) extracts in MDR-Cure lotion.

Greek physician Dioscorides' most appreciated domestic plants are willow, camomile, garlic, onion, marsh mallow, ivy, nettle, sage, common centaury, coriander, parsley, sea onion, and false hellebore. Camomile (Matricaria recutita L.), known under the name Chamaemelon, is used as an antiphlogistic to cure wounds, stings, burns, ulcers and abortion. Pliny the Elder (23-79 AD) wrote about approximately 1000 medicinal plants in his book Historia Naturalis. Liber Magnae Collectionis "Simplicum Alimentorum Et Medicamentorum” by Ibn Baitar (1197-1248) 
has monumental evidences to use plants as medicine. Marco Polo's Journeys (1254-1324) in tropical Asia, China, and America (1492), and Vasco De Gama's Journeys to India (1498), resulted in many medicinal plants being brought into Europe for research [3]. Between 16th and 18th centuries, the demand for compound drugs was increased which were made by medicinal plants, animal parts and minerals. The major concepts were if you concentrate the drug parts, then it cures the disease effectively. However, the methods of preparation of drugs from plants were questioned in the $19^{\text {th }}$ Century and thus in the $20^{\text {th }}$ Century such modifications were followed by clarifying the utility of many medicinal plants like Opium, Styrax, Colchicum and Ricinus [9]. In present days herbal pharmacopoeias lead this world like PhEur 6, USP XXXI, and BP 2007 prescribed plant drugs having real medicinal value. Thin Layer Chromatography, Gel Filtration using Sephadex-G columns and HPLC gave pure chemical to cure diseases and chemical nature of the active compounds were determined by MASS, NMR and FTIR Spectrometry [16]. Truly, there are reports that pure chemical is more-antibacterial but at the same time is very toxic to health and dose must be carefully evaluated in children.

\subsection{Production of Penicillin Antibiotic and Goodbye of Herbal Remedies}

Antibiotics means chemicals that oppose life ("Anti" means inhibition and "Bios" means life). What are the characters of a good antibacterial? We can say many important characters, as for examples: (i) Selective target and does not bind bio-molecules of host organs, (ii) Bactericidal - It must kills the bacteria and should not be bacteriostatic, (iii) Narrow spectrum - does not kill helpful bacteria of intestine, (iv) High therapeutic index - ratio of therapeutic level to toxic level, (v) Few adverse reactions - toxicity, allergy, vomiting, diarrhoea will not occur, (vi) Various routes of administration intravenous (i.v), intramuscular (i.m) and oral, (vii) Good absorption in the intestine, and (viii) Good distribution to site of infections like brain, or kidney and tissues. It takes $\sim 2$ billion dollars to get approval of one drug into market worldwide [3]. Also for four clinical trial stages need 5-10 years research, apart time needed for basic research of drug development. Thus, new drug discovery with new target has diminished modern days although drug-target interactions could be predicted early by computer-software guided technologies and crystallography as well as due to advancement of synthetic organic chemistry. Thus, major drug research activities between (1960-1990) are based on alteration of chemical structure to get better drug in a way that the target site would not be altered and were resistant to penicillinases, drug-acetyltransferases and drug-phosphotransferases [11]. In principle, core drug structure will be same and the different side chains will be added or altered and then new drug will be assayed if MIC has diminished, toxicity lowered, resistant to $\beta$-lactamases and many other pharmacokinetic parameters must show better than the parent drug. In a different way one atom may be changed in the core structure with or without changes in the side chains and then get a superior drug as in carbapenem drugs "S: atom of B ring changed into " $\mathrm{C}$ " atom and changes in side change of imipenem gave better stable potent drugs, meropenem and doripenem those mostly used now against MDR infections. Such technologies are so well effective that sometime bacteria-actinomycetes-fungi based fermentation technologies are abandoned and total chemical synthesis of the drug is followed even it is multiple steps and obviously such drugs are very costly.

Penicillin $1^{\text {st }}$ discovered in 1928 by Alexander Flaming as he looked his old agar-media plates with Staphylococcus bacteria which were lysed by some fungus contamination. He immediately grew the fungus and was found the supernatant was actively killed the bacteria in vitro [18]. It took until 1943 to commercialize benzyl penicillin for public use due to two World Wars. Benzyl penicillin was prepared by the fermentation process using Penicillium notatum, the fungus discovered by Flaming. Further refinement was made by introducing better strains of fungi like Penicillium crysogenum. After Flaming's paper was published, there was total madness worldwide to discover new drugs against Koch's pathogens. Surprisingly, a penicillinase enzyme was discovered in 1940 that could break penicillin into useless penicillinic acid that could not stop bacterial peptidoglycan biosynthesis mimicking D-Ala-D-Ala portion of the peptide chains [19]. Merck (New York, NY) and Andrew Jackson Moyer each filed patents on the process of penicillin production using Penicillium baculatum with a modified method than Flaming, On March 1, 1944, Pfizer opened the first commercial plant for large-scale production of penicillin by submerged culture in Brooklyn (New York, USA) increasing penicillin production to 1663 billion units. Alexander Fleming, Howard Florey, and Ernst Chain were awarded the Nobel Prize in Physiology or Medicine in 1945 for their penicillin research. Dorothy C. Hodgson won Chemistry Nobel in 1964 for structure elucidation of penicillin (1946) as well as B12 (1956). In the United Kingdom, penicillin first went on sale to the general public, as a prescription only drug, on June 1, 1946. This is the turning points of drug industry in the USA regarding drug development, patenting and gain of huge royalty worldwide. Different penicillin drugs derivatives were developed in 1960s against early penicillinases (amp gene homologue) and finally it is time for carbapenem drugs introduced in 1980s but newer derivative of inhibitors like avibactam and sulbactam were used in combination therapy against MDR pathogens. Since then new and newer drugs, huge capital market, huge propaganda from pharmaceutical companies were occurred and we ingested 200000 tons antibiotics per year to eradicate $>3500$ species of gut microbiota that synthesize 20 vitamins for $>30000$ biohemical reactions called human metabolosome [20].

\subsection{Ubiquitous Appearance of MDR Bacteria}

Microorganism is most important for us as we cannot produce vitamins. Bacteria reside in our intestine as bio-film and produce vitamins for us. Microorganisms also express 
many hydrolases, glycosyltransferases and polysaccharide lyases as in Bacteroides thetaiotaomicron 260 hydrolases have been reported that even are not present in $3.6 \times 10^{9} \mathrm{bp}$ DNA or 23 pairs human chromosomes. Similarly, other microorganisms like Bacteroides, Roseburia, Bifidobacterium, Fecalibacterum and Enterobacterium are involved in carbohydrate metabolism with production of butyrate, acetate and propionate nutrients that are involved in molecular signalling to intestinal cells [21]. Similarly, pathogenic bacteria like Helicobacter, Vibrio, Salmonella species in stomach, Enterocus, Bacteroides fragilis in luminal., Clostridium sp., Prevotella sp. and Akkermansia muciniphila in intestinal mucus layer are important in bio onversion, vitamin biosynthesis and immune-modulation. Other study indicated that oxalate was removed by Oxalobacter formigenes and Lactobacillus species preventing kidney stones. Intestinal Escherichia coli and Bacteroides intestinalis have role in modulation of bile acids into deoxycholic acid and lithoc olic acid. Never the less, roles of Helicobacter pylori in promoting cancer have been established but now debated. But in peoples mind first and last thing are to take sufficient antibiotics to clear unseen stomach and intestinal bacteria. Technology like Microbial Culturomics help to detect and isolate previously uncultured gut bacteria for typing against hundred of antibiotics and bacteriophages to understand the generation of MDR bacteria with new gene creation (The human Microbiome Jumstart Reference Strains Consortium, 2010). Gut microbiota population greatly vary with age but most bacteria could be found within age 3 and changes in such diverse populations cause serious health hazards like obesity, cancer, diabetes and others. Rapid and repeated destruction of such microbiota by antibiotic uses since 1940s have caused serious communications gaps due to poor synthesis of LPS, vitamins and other complex chemicals. Now more and more new genes will be seen in plasmids (each 100-500kb MDR conjugative plasmid carry $\sim 20$ unknown genes) due to rapid DNA sequencing methods [22, 23]. No doubt free cost of NCBI database and BLAST search technologies now have facilitated bacterial genome sequencing at every college and research institution of the developing countries.

Most importantly, how the microbiome is affected by antibiotics and how the microbiome affects the response to various drugs [40]? We gave probiotics and vitamins during antibiotic therapy. However, hardly all patients in this Earth receive those nutrients after antibiotic therapy. Pérez-Cobas et al. (2012) studied the gut microbial communities in faecal samples taken at multiple time points from an individual subjected to $\beta$-lactam therapy. It was found that the Firmicutes were the most abundant active phylum in the most samples during treatment but the Lachnospiraceae and Rumino coccaceae families constituted the most abundant taxa on days 3 and 6 of antibiotic treatment where as Proteobacteria and Bifidobacteria were greatly diminished. However, certain taxa, such as Actinobacteria (Slackia and Bifidobacterium genera), $\beta$-proteobacteria (Gemmiger genus), Streptoccaceae (Streptococcus genus), Lachnospiraceae (Roseburia genus), Porphyromonadaceae (Barnesiella genus) and Clostridiales
(Eubacterium genus) were not detected or drastically lowered. [23]. Short term antibiotic exposure was not too bad but long term antibiotic use had detrimental effects on the gut microbiome and likely gut microbiome was the site for $m d r$ genes creation and spread [24]. In India many people were still prescribed for ampicillin and tetracycline as well as old drugs like sulfamethoxazole, trimethoprim and ciprofloxacin which essentially useless now due to abundance of blaTEM, tet $A / C$, blaCTX-M, dhfr and sull/2 $m d r$ genes in environmental bacteria. We found $40 \%$ river and sea bacteria in India were drugs resistant and 95\% clinical isolates worldwide were penicillin drug resistant. Similarly, Qu et al. (2008) studied the microbiome of chicken gut. In total, 117 established genera of bacteria were represented by the $16 \mathrm{~S}$ rRNA sequence analysis with most genera belonging to the phyla Firmicutes, Proteobacteria, and Bacteroidetes. Phylum Firmicutes, Bacteriodes and Proteobacteria were represented major bacteria with Genus Clostridium, Lactobacillus and Delsulfohalobium and Bacteroidetes [25]. Thus, gut microbiome change is a serious threat today for all life forms and during the 70 years of huge antibiotic use, drastically changed the plasmid content of all bacteria inducing AMR and drug void [26].

\subsection{Demand for Alternate to Antibiotics}

Antibiotic void is real and threatening. Since 2013 we are studying the Kolkata Ganga River superbugs and our data indicated that $>40 \%$ bacteria are ampicillin and amoxicillin resistant and $26 \%$ are resistant to ciprofloxacin and tetracycline. Those two drugs are wide spread use in human and animal to cure many infections since 1940s [26]. Surprising fact was observed that cefotaxime, imipenem, meropenem, amikacin, linezolid, azithromycin, lomofloxacin types most potent drug derivatives resistant species were also prominent (0.02-0.002\%). We detected easily blaTEM, aacA1, blaNDM1 and acrAB types genes in plasmids which are large and heterogeneous. Such study is important and indicates that MDR infection may occur any time to anyone [27]. Our study also indicates MDR contamination in Kolkata rain water and MDR spread to any place may thus possible during rain and storm. Thus WHO and UN have warned for the development of alternate to antibiotics unless calamity with 2-3\% GDP loss in India (Indian GDP $=2.6 \times 10^{6}$ million dollars) may hit severely due to high air and water pollution (PM10 $200-500 \mu \mathrm{g} / \mathrm{m}^{2}$ and BOD $7.4 \mathrm{mg} / \mathrm{L}$ ) as well as huge population burden (1350 million) [8].

\subsection{Re-Appearance of Phyto-Antibiotics in Pure Form}

Scientific development of drugs is largely favour with pure entity. The plant chemicals were first solubilised in water or methanol or mixture of both and then silica-gel column chromatography was performed to separate abundant chemicals. Then after bio-assay such partially pure chemicals were purified by partition chromatography between different organic solvents using High Performance Liquid Chromatography (HPLC). Quinine, taxol, artiminisin, 
resveratol, serpentine, and etoposide are plant-derived almost pure antibiotics eradicating malaria, cancer and bacterial infections in modern days. Taxol was purified from the bark of Taxus brevifolia or Taxus wallichiana $(<0.05 \%)$ and very effective drug for ovarian, breast and lung cancers [27]. Raw material was grounded, extracted in methanol (1:3) in a Soxhlet apparatus. The extract mixed with silica gel and dried in rotary evaporator under vacuum at $40^{\circ} \mathrm{C}$. Interesting fact is that a $\mathrm{CO}_{2}$ supercritical fluid extraction (LAB SFE from Separex) work well at 500 bar and $150^{\circ} \mathrm{C}$ for $3 \mathrm{hrs}$. Also total chemical synthesis of taxol has made [28]. Artiminisin (Qinghaosu) was isolated from Artemisia annua leaves (wormwood) in 1972 as anti-malarial drug against chloroquine-resistant falciparum malaria by Chinese scientist $\mathrm{Tu}$ Youyou who won 2015 Nobel prize in medicine. It is extracted with ethanol, hexane and petroleum ether with $(15 \%$ recovery) but liquid $\mathrm{CO}_{2}$ supercritical extraction (>50\% recovery) has favoured in commercial isolation. A silica gel chromatography in acetonitrile medium following slow water addition (anti-solvent) creates orthorhombic pure crystal of artiminisin [29]. Now-a-day artimisinic acid was produced in S.cerevisiae with genetically engineered highly expressed $A$. annua CYP71AV1, CPR1 and CYB5 genes under inducible GAL promoter [30].

\subsection{Development of Phyto-Antibiotics in Cancer Therapy}

Taxol is used as i.v. injection to treat cancer types like ovarian cancer, breast cancer, lung cancer, Kaposi sarcoma, cervical cancer, and pancreatic cancer. On 21 August 1962, Arthur S. Barclay, collected bark from a single Pacific yew tree, Taxus brevifolia, in a forest north of the town of Packwood, Washington and extract was found to be cytotoxic to cancer cells. By 1969, $28 \mathrm{~kg}$ of crude extract had been isolated from almost $1,200 \mathrm{~kg}$ of bark and $10 \mathrm{gms}$ taxol was obtained for clinical research. Animal toxicology studies were completed at NCI on June 1982 and next followed human clinical trial. There were overwhelming response from cancer patients as Dr. Gordon Cragg of the NCI estimated they needed bark from 360,000 trees annually. American firm Bristol-Myers Squibb got permission (Cooperative research and development agreement) to market the drug in 1992. In october 2007 it was approved by Drug controller General of India for the treatment of breast cancer and launched in collaboration with Biocon Pharmaceuticals [31, 32]. Similarly thousand ethanol plant extracts screened by NCI for anticancer efficacy, extract of Camptotheca acuminate was effective to inhibit cancer cell lines and xeno-graft in mice. Camptothecin (see, figure 1) induce DNA damage and later Dr. Hsiang confirmed topoisomerase 1, not topoisomerase 2 , is the molecular target of camptothecin. Transgenic plants (agrobacterium-mediated) with over-expressed cDNA of TDC (tryptophan decarboxylase), STR (Strictosidine synthase) and GH (Geraniol 10-hydroxylase) genes has now produced enough camptothecin $(0.012 \%$ of dry weight) in hairy roots culture in MS tissue culture media [33].

\subsection{Development of Phyto-Antibiotics Against Malaria}

Quinine (see, figure 1) was first isolated in 1820 from the bark of a cinchona tree while bark extracts was used to treat malaria since at least 1570 s in the Europe. Nicolás Monardes (1571) and Juan Fragoso (1572) both described the cinchona tree and whose bark was used to produce a drink to treat diarrhoea. It was first used to treat malaria in Rome in 1631 as malaria was responsible for the deaths of several popes, many cardinals and countless common Roman citizens. Agostino Salumbrino (1564-1642) likely utilized bark extract first to reduce the shivering fever of malaria. Cinchona bark, known as Jesuit's bark or Peruvian bark, became one of the most valuable commodities shipped from Peru to Europe to cure King Charles II at the end of the 17th Century in London. In 1820, French researchers Pierre Joseph Pelletier and Joseph Bienaimé Caventou first isolated quinine from the Cinchona bark substance $[1,3]$. The name was derived from the original Quechua (Inca) word for the cinchona tree bark, quina or quina-quina, which means "holy bark". Prior to 1820, the bark was first dried, ground to a fine powder, and then mixed into a liquid (commonly wine) which was then drunk. Large-scale use of quinine as a malaria prophylaxis started around 1850 with successful, colonization of British and French in Africa (Gold Coast, Nigeria) which was known as White Man's Grave at that time. To maintain their monopoly on cinchona bark, Peru and surrounding countries began outlawing the export of cinchona seeds and saplings beginning in the early $19^{\text {th }}$ Century. The Dutch government persisted in its attempts to smuggle the seeds, and in the late $19^{\text {th }}$ Century to reduce the monopoly of cinchona bark of Peru. Dutch managed to grow the plants in their Indonesian plantations and soon they became the main suppliers of the plant, and in 1913 onwards with production of 22 million pounds of cinchona bark $(97 \%$ of the world's quinine production). During World War II, Allied powers were cut off from their supply of quinine leading tens of thousands of US troops in Africa and the South Pacific died in malaria due to the lack of quinine. The United States had managed to obtain four million cinchona seeds from the Philippines and began operating cinchona plantations in Costa Rica. Quinine remained the anti-malarial drug of choice until after World War II, when other drugs, such as chloroquine, that have fewer side effects largely replaced it. Bromo Quinine was brand name of tablets containing quinine, manufactured by Grove Laboratories around the year 1889 and available until at least the 1960s [34].

Artemisinin (see, figure 1) was isolated from the plant Artemisia annua (sweet wormwood), a herb employed in Chinese traditional medicine. It was discovered in 1972 by Tu Youyou, a Chinese scientist, who was awarded half of the 2015 Nobel Prize in Medicine for her discovery. Artemisinin-combination therapies (ACTs) are now standard treatment worldwide for P. falciparum malaria [35]. In April 2013, Sanofi Pharmaceutical started production of artemisinic acid in Garessio, Italy, with worldwide collaborative funding from the Bill \& Melinda Gates Foundation. The process was initially designed by Jay Keasling at the University of 
California, Berkeley and optimized by Amyris. In 2006, a team from UC Berkeley Scientists reported that they had engineered Saccharomyces cerevisiae to produce artemisinic acid and chemically converted into artemisinin that they claim will cost roughly $\$ 0.25$ per dose. The yeast cells were engineered to express the enzyme amorphadiene synthase and a cytochrome P450 monooxygenase (CYP71AV1), both from A. annua where three-steps oxidation of amorpha-4,11-diene gives the resulting artemisinic acid [36]. The process of chemical synthesis was continued and the major success of optimized synthesis of artiminisin was achieved in 2012, followed by commercial production in 2014 [37].
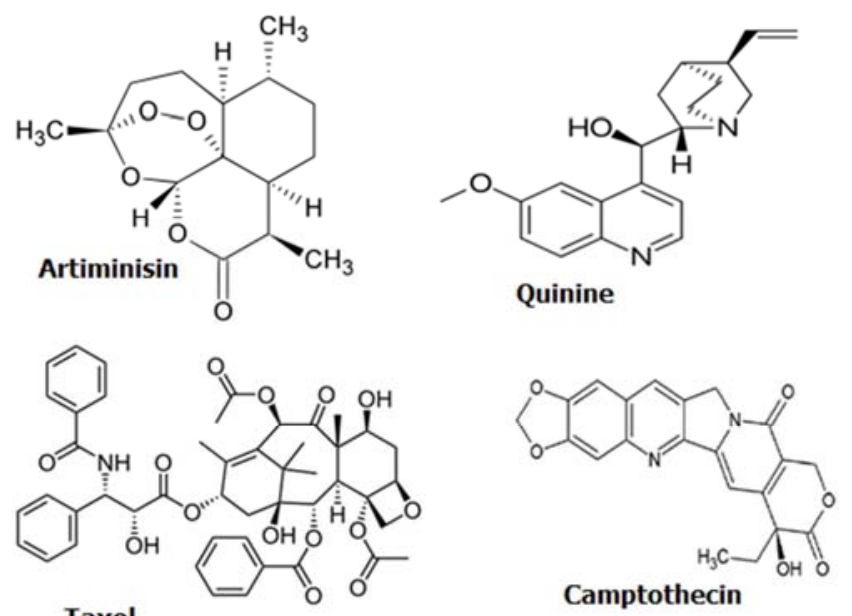

Taxol

Camptothecin

Figure 1. Structure of well known plant derived drugs against cancer and malaria.

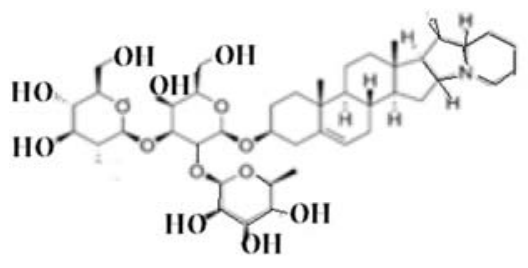

Saponin<smiles></smiles>

Polyphenol

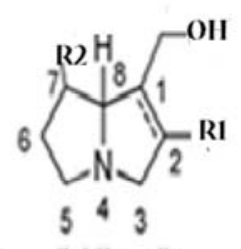

Alkaloid

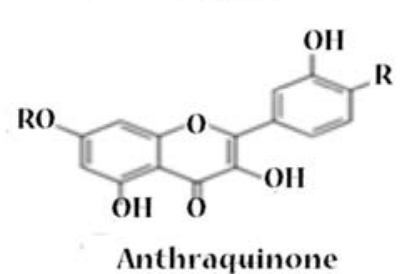

Figure 2. Different types of phyto-chemicals isolated from plants.

Thus, we see huge potential of plant-derived antibiotics to cure bacterial infection as well as for the treatment of diabetes, cancer as well as other fungal, parasitic and viral pathogenesis. We have given the structures of some important alkaloids, flavones and phenolics those have been shown have antibacterial activities and anti-oxidant activities (see, figure 2). Such compounds may be commercially used as drugs similar to taxol, artiminisin and quinine. We have isolated
CU1 from Cassia fistula bark likely saponin having RNA polymerase target and bacteriostatic at low concentration. Similarly, NU2 flavones has DNA topoisomerase I target isolated from Suregada multiflora root (unpublished data).

\section{Methods: Isolation of MDR Bacteria, Purification of Phyto-Chemicals and Identification}

\subsection{Isolation of MDR Bacteria and Their Characterization}

Water from Ganga River was collected at the morning from Babu Ghat (Kolkata-700001) and Howrah Station River. About $100 \mu 1$ of water was spread onto $1.5 \%$ Luria Barton-agar plate containing different concentration of antibiotics at $2-50 \mu \mathrm{g} / \mathrm{ml}$. MDR bacteria were selected in agar-plate containing ampicillin, streptomycin, chloramphenicol, tetracycline or ciprofloxacin at 50, 50, 34 and $20 \mu \mathrm{g} / \mathrm{ml}$ respectively. As imipenem and meropenem resistant bacteria were present low (0.08-0.2 cfu/ml water), a modified method was followed. $2 \mathrm{ml} 5 \mathrm{x}$ LB media was added into $10 \mathrm{ml}$ River/Sea water at $2-10 \mu \mathrm{g} / \mathrm{ml}$ drug concentration and was incubated $24 \mathrm{hrs}$ to get drug resistant bacteria population [5]. Meropenem resistant bacteria were further selected on tetracycline, chloramphenicol and streptomycin to get the superbugs. Antibiotics were purchased from HiMedia and stored at $2-50 \mathrm{mg} / \mathrm{ml}$ at $-20^{\circ} \mathrm{C}$. Antibiotic papers were also purchased from HiMedia according to CLSI standard. Antibiotic papers are: A-25 (ampicillin), T-10 (tetracycline), AT-50 (aztreonam), COT-25 $\mu \mathrm{g}$ (cotrimoxazole), Met-10 $\mu$ g (methicillin), CAZ-30 $\mu \mathrm{g}$ (ceftazidime), LOM-15 $\mu \mathrm{g}$ (lomofloxacin), VA-10 $\mu \mathrm{g}$ (vancomycin), AK-10 $\mathrm{g} \quad$ (amakacin), $\quad \mathrm{TGC}-15 \mu \mathrm{g}$ (tigecycline), LZ-10 $\mu \mathrm{g}$ (linezolid), and IMP-2 $\mu \mathrm{g}$ (imipenem).

The plasmid DNA was isolated from overnight culture using Alkaline-Lysis Method. Chromosomal DNA was isolated by proteinase K-SDS method. 16S rDNA gene colour Sanger's di-deoxy sequencing [6] was performed by SciGenom Limited, Kerala, India, using colour-ddXTPs, dXTPs, $\mathrm{MgCl}_{2}$ and DNA polymerase and separated on polyacrylamide gel electrophoresis followed by laser detection of coloured DNA fragments (figure 3, Section II). PCR amplification was performed using 1 unit Taq DNA polymerase, 20ng DNA template, $0.25 \mathrm{mM} \mathrm{dXTPs}, 1.5 \mathrm{mM} \mathrm{MgCl}_{2}$, for 35 cycles at $95^{\circ} \mathrm{C} / 30^{\prime \prime}$ (denaturation) $-52^{\circ} \mathrm{C} / 50^{\prime \prime}$ (annealing) $-72^{\circ} \mathrm{C} / 1.5^{\prime}$. The product was resolved on a $1 \%$ agarose gel in $1 \mathrm{X}$ TAE buffer at $50 \mathrm{~V}$ for $4 \mathrm{hrs}$ and visualized under UV light and photograph was taken (figure 3, section III). NCBI BLAST analysis was performed for bacterial specific gene analysis (www.ncbi.nlm.nih.gov/blast) and data was submitted to GenBank. NCBI databases were retrieved using the BLAST programmes [8]. 

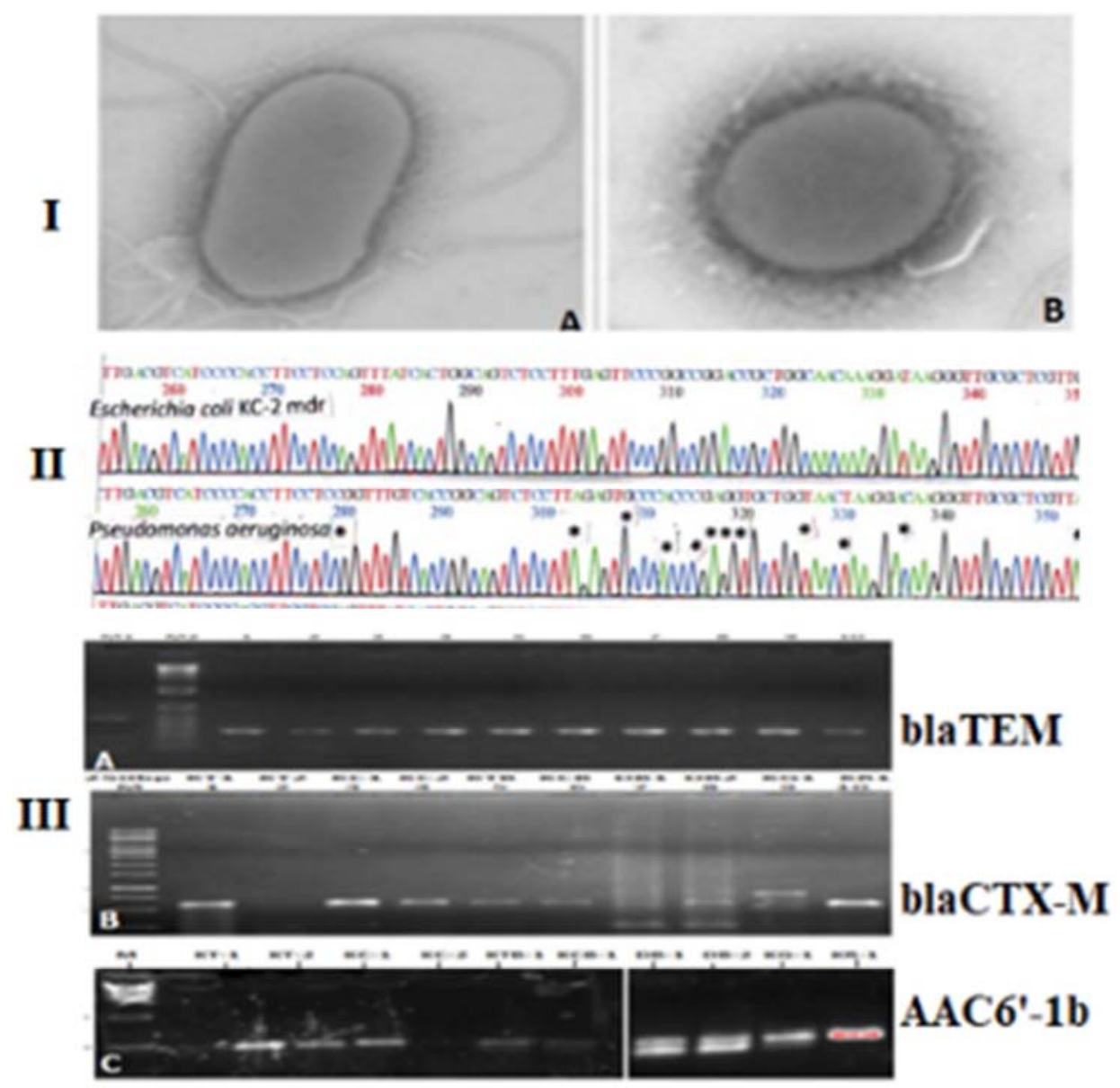

Figure 3. Characterization of MDR bacteria by EM (I) PCR, $16 \mathrm{~S} r R N A$ Sequencing (II) and PCR with mdr genes specific probes (III) [5, 8].

\subsection{Procedure of Extraction of Phyto-Antibiotics}

Most of the phyto-chemicals from plant sources such as phenolics, flavonoids and alkaloids have been reported to have positive impact on health like cancer prevention, wound healing and anti-inflammatory activity. High content of phenolics and flavonoids in medicinal plants have been associated with their antioxidant activities that play a role in the prevention of the development of age-related diseases, particularly caused by oxidative stress. In ancient methods, plant parts are chopped with knife and pasted with the help of two stones in presence of water or wine. Traditional updated methods such as Maceration and Soxhlet extraction are commonly used at the small research setting or at Small Manufacturing Enterprise (SME) level. Modern extraction methods; microwave-assisted (MAE), ultrasound-assisted extraction (UAE) and supercritical fluid extraction (SFE), in which these advances are aimed to increase yield at lower cost and may also increase stability of active alkaloids and aromatic compounds [38]. The various methods are optimized for individual plants and targeted recovery of particular chemical. During pre-extraction, we can use fresh or air-dried sample, grinded or powdered plant parts and drying condition may vary from air-drying to microwave-drying or freeze-drying. The extraction may be defined by maceration, infusion, percolation and decoction. Maceration involved soaking plant materials in a container with a solvent in tight condition and allowed to stand at room temperature for a period of minimum 3 days with frequent agitation. The process intended to soften and break the plant's cell wall to release the soluble phyto-chemicals. For heat stable compounds, dried powder samples are packed in the percolator, added with boiling water and macerated for 2 hours to get phyto-chemicals quickly. Water is a bad solvent for alkaloid extraction. Orthosiphonstamineus (tea additive herb) bioactive phyto-chemicals; such as sinensetin and rosmarinic acid content were affected by the oven and sunlight-drying, suggesting the sensitivity of the compounds to temperature. Accelerated solvent extraction (ASE) and supercritical fluid extraction (SFE) are updated methods for quick extraction of bioactive compounds within 2-5 hours. Supercritical fluid shares the physical properties of both gas and liquid at its critical such as temperature and pressure. Even though $\mathrm{SC}-\mathrm{CO}_{2}$ has poor solubility for polar compounds, modification such as adding small amount of ethanol and methanol enable it to extracts polar compounds $[39,40]$. We advocate wine extraction of medicinal plants to cure MDR infections at home as ethanol is restricted to open sell. Methanol is cheap but smell is unhealthy and toxic. So complete evaporation is needed to consume or for assay of anti-bacterial activity. For simplicity, We take $5 \mathrm{gm}$ fresh root or bark (for example, Suregada multiflora) in a $50 \mathrm{ml}$ plastic tube and add $40 \mathrm{ml}$ ethanol and kept at room temperature $\left(<37^{\circ} \mathrm{C}\right)$ for 1 day with screw cap tight. Then dried at room 
temperature to concentrate 5 times and use as lotion or consume directly three times/day. It cures MDR nail infection by applying 3 times/day/3days [5, 8]. Rat feed such extract $97 \%$ lowered the Escherichia coli KT-1_mdr infection which was resistant to ampicillin, tetracycline, azithromycin, sulfamethoxazole and ciprofloxacin but sensitive to imipenem and tigecycline.
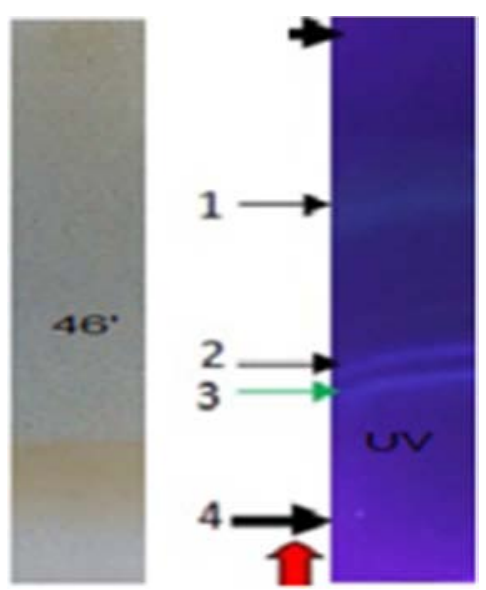

Figure 4. Preparative Thin Layer Chromatography and UV Shadowing to detect active chemicals of Suregada multiflora root ethanol extract [8].

\subsection{Roles of TLC and HPLC in Active Principle Purification}

TLC is Thin Layer Chromatography where a thin layer of alumina power, some time mixed with binders like calcium carbonate, in a glass plate was made. The chemical solution was spotted on the plate (in few milli meter diameter broad band as in preparative TLC, figure 4) and vertically plunged into an organic solvent in a glass jar (with a cover) so that solvent do not touch the spot. The solvent we use is a mixture of methanol, water and acetic acid (50:40:10) or similar composition varying water concentration or adding $10-20 \%$ butanol, ethyl acetate or acetone lowering methanol and water concentration. Ammonium hydroxide in place of acetic acid inactivates active principles from Cassia fistula [8]. As the solvent go upwards, the chemicals were separated as their partition coefficient between solid phase and solvent phase. It takes less than one hour $(14 \mathrm{~cm} x 8 \mathrm{~cm}$ plate) and very good to separate a mixture of hydrophobic and hydrophilic compounds. The plate was dried and the chemicals could be seen by different ways: (i) the different colour spots cold be collected separately and assayed (ii) the UV shadowing could be used to detect white colour fluoresced different spots of alkaloids and (iii) specific reagents could be sprayed (like ninhydrin solution in alcohol to detect peptide antibiotics) to give colour band of particular compound. We are using preparative gel to collect bioactive plant alkaloid by UV shadowing (figure 4). HPLC is High Performance Liquid Chromatography where high pressure column chromatography used to separate bio-molecules into a pure form [41]. We use $\mathrm{C}_{18}$-column to separate plant alkaloid (usually partially purified by double TLC) and the sophisticated technology laser detected the fractions accurately and quantity was measured if a standard alkaloid with known concentration was run in the same column. A typical spectra showing a small contamination was shown (figure 5).

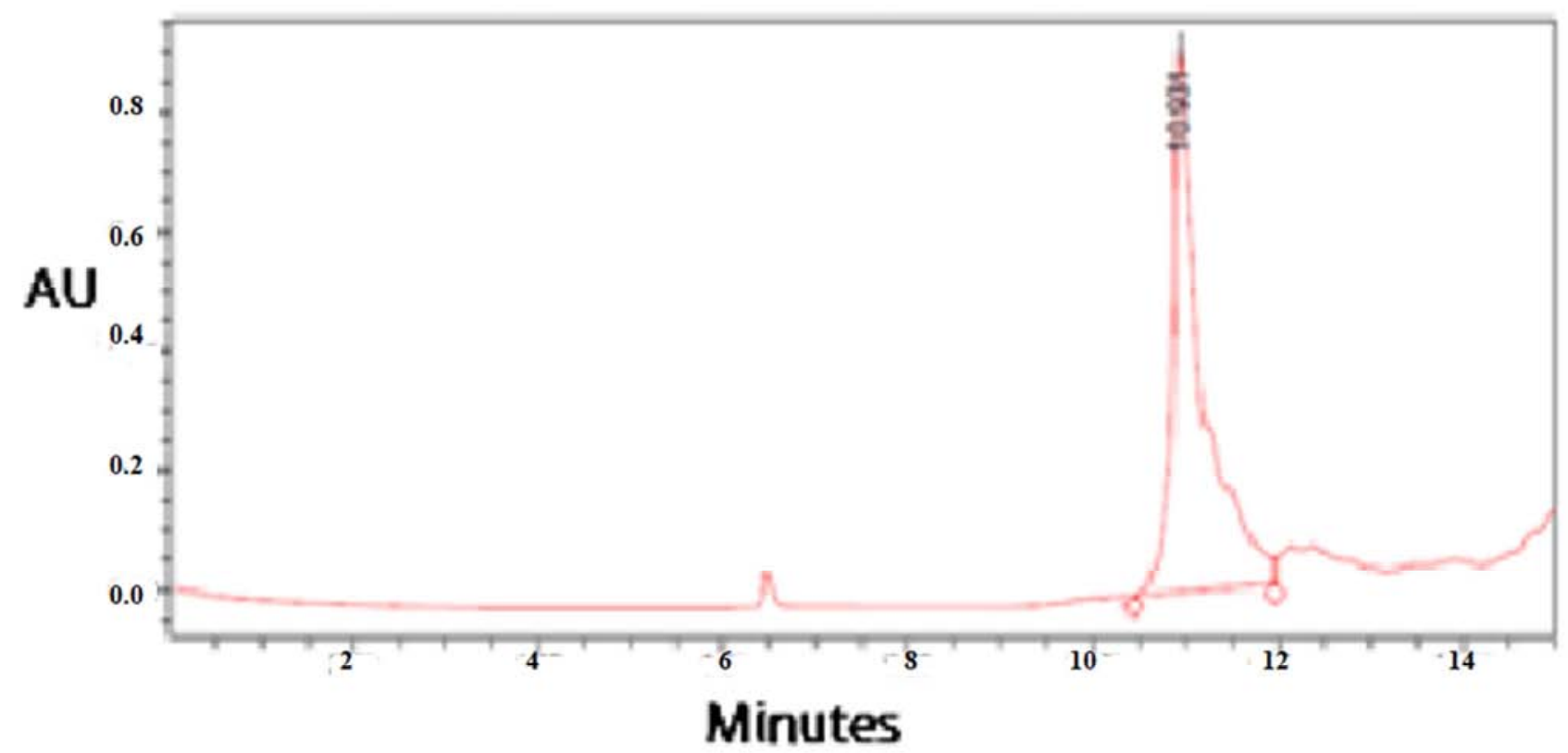

Figure 5. A typical HPLC spectra of high pressure chromatography where $0.1 \mathrm{ml}$ sample loaded onto $5 \mathrm{ml} C_{18}$ column and fractions eluded were detected by laser technique.

\subsection{MASS Spectrometry}

A mass spectrum is an intensity vs. $\mathrm{m} / \mathrm{z}$ (mass-to-charge ratio) plot (histogram) which is unique for any plant alkaloid. Usually, pure chemical was bombered by electron beam and +ve charged particles were deflected in high intensity magnet, 
separating molecular ion and its fragments using a mass Spectrometer which consisted of three components: an ion source, a mass analyzer, and a detector. Common fragmentation processes for organic molecules are the McLafferty rearrangement and alpha cleavage representing unique multiline graph to identify a similar molecule and its derivatives. Lighter ions get deflected by the magnetic force more than heavier ions based on Newton's second law of motion, $\mathrm{F}=$ ma. In 1911, J. J. Thomson determined the e/m of an electron which is 1811 times less than a hydrogen ion. Francis W Aston introduced Mass Spectrograph and won Nobel Prize in 1922. In 1918, Arthur J Dempster reported a mass spectrometer and in 1935 detected the uranium isotope ${ }^{235} \mathrm{U}$. In 1932, Kenneth Bainbridge developed a mass spectrometer with a resolving power of 600 and a relative precision of one part in 10,000 [42]. He used this instrument to verify the equivalence of mass and energy, $\mathrm{E}=\mathrm{mc}^{2}$. Electrospray ionization invented by John Fenn and matrix-assisted laser desorption/ionization (MALDI) by M. Karas, F. Hillenkamp and K. Tanak to obtain Nobel in 1987. Fourier transform ion cyclotron resonance mass spectrometry was developed by Alan G Marshall and Melvin B Comisarow at the University of British Columbia in 1974. Interestingly, data were assembled into computer algorithm in a way, now you know the structure of your unknown sample immediately from computer. However, such software is costly [43].

\section{5. ${ }^{1} \mathrm{H}$-NMR and ${ }^{13} \mathrm{C}$-NMR Spectroscopy}

Nuclear Magnetic Resonance (NMR) is a spectroscopic technique to detect local magnetic moment around odd atomic nuclei bombed with radio waves. The most commonly used small molecules are hydrogen $\left({ }^{1} \mathrm{H}\right)$ and carbon $\left({ }^{13} \mathrm{C}\right)$ but other ${ }^{11} \mathrm{~B},{ }^{19} \mathrm{~F},{ }^{23} \mathrm{Na},{ }^{31} \mathrm{P},{ }^{35} \mathrm{Cl}$ etc also have been used using NMR. At a low energy radio frequency, nuclei magnetic spin quantum energy could be represented by: $E=-\gamma \mathrm{mhB}_{0}$, where $\mathrm{B}_{\mathrm{o}}$ is the field strength, $m=$ magnetic spin quantum number, $\gamma=$ gyromagnetic ratio and h is Plank's Quantum number [44]. For data analysis, NMR absorption spectra was adjusted to Chemical Shift $(\delta)$ using Tetra Methyl Silane (TMS) as standard and data was expressed as ppm (parts per million). TMS is chemically inert, magnetically isotropic, miscible with most organic solvent and absorbs at higher frequency than all common types of organic protons. $\delta=\Delta \mathrm{v} \times 10^{6} \%$ oscillator frequency in cps where $\Delta v$ is the difference in magnetic spin absorption frequencies of the sample and the reference in cps (cps 700 cycles per second). A NMR spectra of a plant derived chemical CU1 (Cassia fistula Bark) was presented in figure 6 (unpublished).

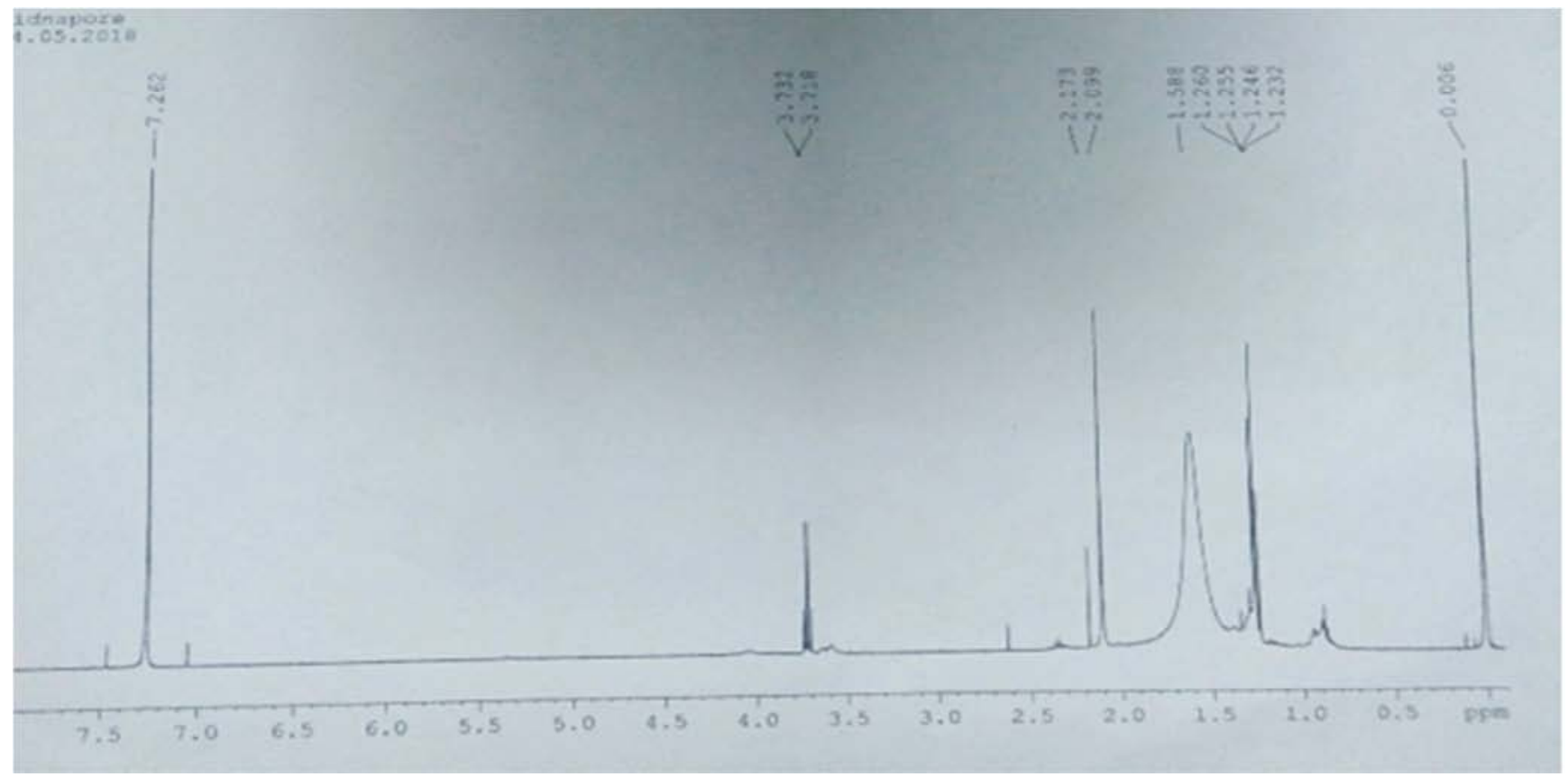

Figure 6. ${ }^{I} H_{1}$ NMR Spectra of purified CU1 chemical from Cassia fistula which inhibits Escherichia coli RNA polymerase

\subsection{FT-IR Spectrometry}

Infrared spectra gives an idea of functional groups of a compound. Wave number $\left(\mathrm{v} \mathrm{cm}^{-1}\right)$ is used to measure the infrared absorption at $4000-667 \mathrm{~cm}^{-1}(2.5-15 \mu$ wavelength or $\lambda$ ) where $v=E / h c$ and $\lambda=1 / v ; c=$ velocity of light and $h=$ plank constant. A nonlinear molecule with $\mathrm{n}$ atoms has $3 \mathrm{n}-6$ vibrational modes of stretching, rocking, scissoring, wagging and twisting giving a idea of functional groups of the molecule.
Bending vibration occurs at lower wave number than stretching vibrations. Carbon triple bond absorption at $2300-2000 \mathrm{~cm}^{-1}$, double bond absorption at 1900-1500 $\mathrm{cm}^{-1}$ and single bond at $1300-800 \mathrm{~cm}^{-1}$. Single bond with smaller atom $\mathrm{O}-\mathrm{H}$ stretching absorption at $3570 \mathrm{~cm}^{-1}, \mathrm{C}-\mathrm{H}$ stretching at $3030-2860 \mathrm{~cm}^{-1}$ and same bending at $\sim 1460 \mathrm{~cm}^{-1}$. C=O stretching at $\sim 1725 \mathrm{~cm}^{-1}$ and-N-H stretching at $3500 \mathrm{~cm}^{-1}$ and same bending at $\sim 1650 \mathrm{~cm}^{-1}$. $-\mathrm{C}-\mathrm{N}$ stretching absorption at $1350 \mathrm{~cm}^{-1}$ but $\mathrm{C} \equiv \mathrm{N}$ at $\sim 2200 \mathrm{~cm}^{-1}$ [69]. Typically, 5mg 
HPLC-purified dry active chemical was mixed with $200 \mathrm{mg}$ IR-grade $\mathrm{KBr}$ and the tablet was prepared at $13 \mathrm{~mm}$ Die SET (Kimaya Engineers) at $10 \mathrm{Kg} / \mathrm{cm}^{2}$. Spectra were taken with a Perkin Elmer Spectrum 100 FT-IR Spectrometer (Serial no.
80944) for $10 \mathrm{~min}$. A represented FT-IR spectra of Suregada multiflora NU2 phytochemical was presented in figure 7 indicating - $\mathrm{NH} 2,-\mathrm{OH},-\mathrm{CH} 3$ functional group of an aminoglycosides [8].

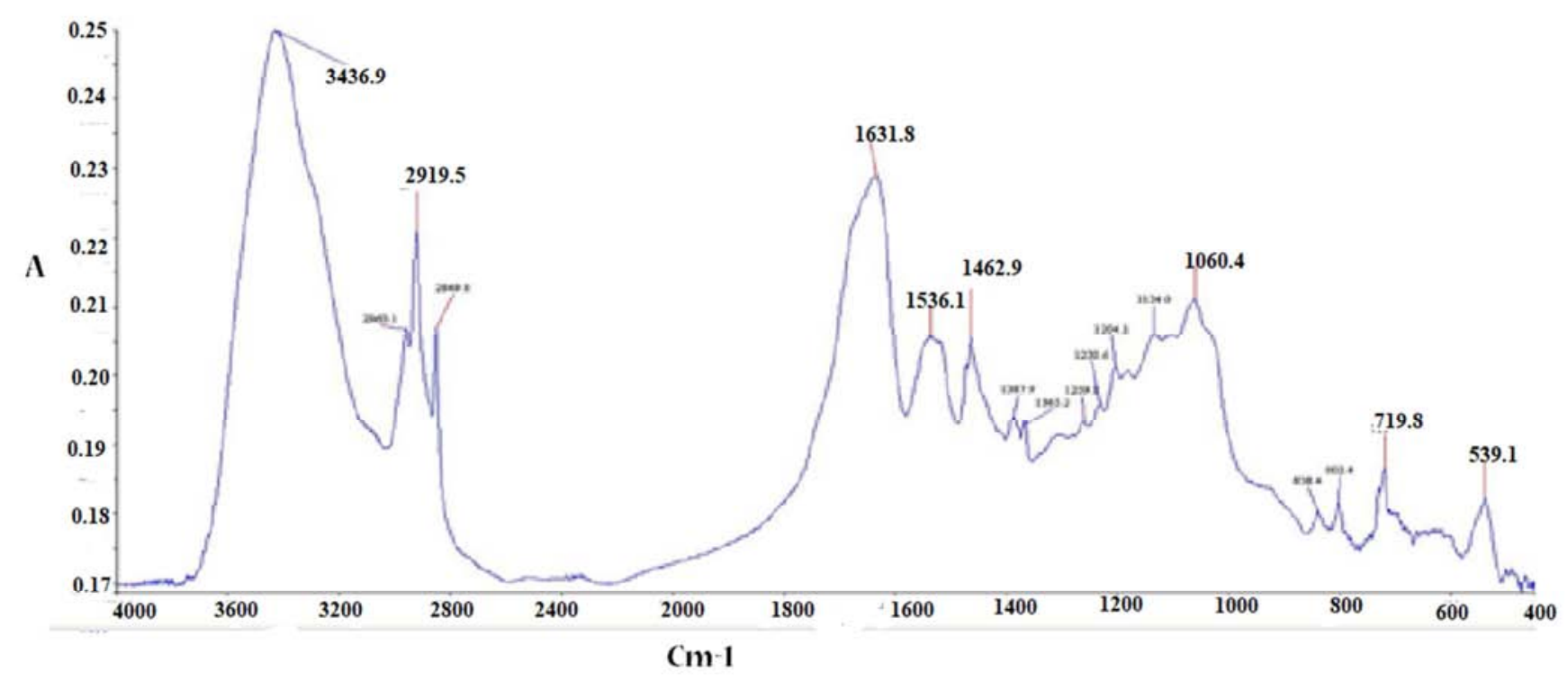

Figure 7. Detection of function groups of the active compound NU2 by FT IR. Peak at 3426.9 is for-N H stretching and-O H stretching; 2960.1 , 2849.8 cm 1 are for- $-\mathrm{CH}_{3}$ stretching; 1631.8 and $1536.1 \mathrm{~cm}-1$ are for $\mathrm{CONH}_{2}$ scissoring; $1462.9,1387.9 \mathrm{~cm}-1$ represent -OH bending likely phenolics; 1259.1 and 1230.6 may represent $\mathrm{C}-\mathrm{NH}_{2} ; 1134.0 \mathrm{~cm}-1$ for $\mathrm{C}-\mathrm{C}-\mathrm{C}$ bending; $802.4 \mathrm{~cm}-1$ for $-\mathrm{NH}_{2}$ wagging; 719.8 may represents $\mathrm{CH}_{2}$ rocking [8].

\section{Advancement of Therapeutics Against Multidrug-Resistant Bacteria}

\subsection{Anti-Bacterial Plant Extracts}

Modern widely used drugs against cancer, malaria and fever like aspirin, vincristine, taxol, quinine, topotecan, epitope and artimisinin are of plant derived [46]. Sadly, we have forgotten our old tradition to cure the diseases using herbal drugs as described in Sanskrit books Charaka Samhita, Satruta Sanhita and Atharva Veda [47]. Discovery of antibiotics and their wide spread use to kill pathogens lead us to forget our own herbal medicine. Astonishingly every year we are using 200000 tons antibiotics creating a dead era of multi-resistance and drug void. Surely, emergence of multidrug-resistant pathogens, high cost and toxicities have encouraged us to trust on natural remedies or herbal medicines again [48]. The fourteen vegetables have been described in Satruta Samhita as wonder mixture to stay safe from diseases if cooked and taken together in the month of october [28].

In India as well as in China, many scientists described the importance of plant derived chemicals to cure multidrug-resistant infections [49]. Clove (Syzygium aromaticum, Myrtaaceae) is one of the most valuable spices that has been used for centuries as food preservative and for many medicinal purposes. The main constituents of cloves essential oil are phenylpropanoids such as carvacrol, thymol, eugenol and cinnamaldehyde [52]. Cinnamon (Cinnamomum zeylanicum) is a common spice used by different cultures around the world for several centuries. It is the inner bark of trees used and contains trans-cinnamaldehyde, eugenol, and linalool [53]. Ool (Amorphophallus campanulatus) belongs to the family of Araceae and is a perinnial herb commonly known as elephant root yam.. The corm contains Betulinic acid, Lupeol, Stigmasterol, $\beta$-sitosterol having anti-bacterial properties. Bathua (Chenopodium album) is Chenopodiaceae family and has anthelminitic, laxative, diuretic, aphrodisiac action. Kalkasunde (Cassia sophera) used in Ayurvedic system of treatment its root is considered as expectorant; bark, leaves and seeds are cathartic; leaves are anti-helmenthic and antiseptic. Neem (Azadirachta indica) has nimbin, a bitter compounds isolated from neem oil has antibacterial activity. Jayanti (Sesbania sesban) is Papilionacae family and widely used to treat sore throat, gonorrhoea, syphilis, and jaundice. Potol (Trichosanthes dioica Roxb.) used as purgative and as tonic, febrifuge, in treatment of jaundice, anasarca and ascites $[54,55]$.

\subsection{Development of Phyto-Antibiotics Against Superbugs}

Interesting finding of our research is, most of the plant's water extract have no antibacterial activity on MDR bacteria and most household plants and herbs of West Bengal have little activities in water extract but organic solvent extract always gave some hope. Thus, to make MDR-Cure, we are constantly searching stable and efficient plant extracts since 2006 at OIST that will kill most MDR bacteria [5, 8]. How we choose the activity in plant extract that has commercial value? If we see the $50 \mu 1$ of $5 \mathrm{x}$ concentrated ethanol extract $(5 \mathrm{~g}$ plant part $/ 40 \mathrm{ml}$ ethanol) has $15-20 \mathrm{~mm}$ diameter lysis zone then we say the plant part has antibacterial activities (figure 8) as 
compared with $10 \mu \mathrm{l}$ of $34 \mathrm{mg} / \mathrm{ml}$ chloramphenicol or $50 \mathrm{mg} / \mathrm{ml}$ ampicillin which would be produce $20-30 \mathrm{~mm}$ lysis zones) using Escherichia coli DH5a [14, 38].

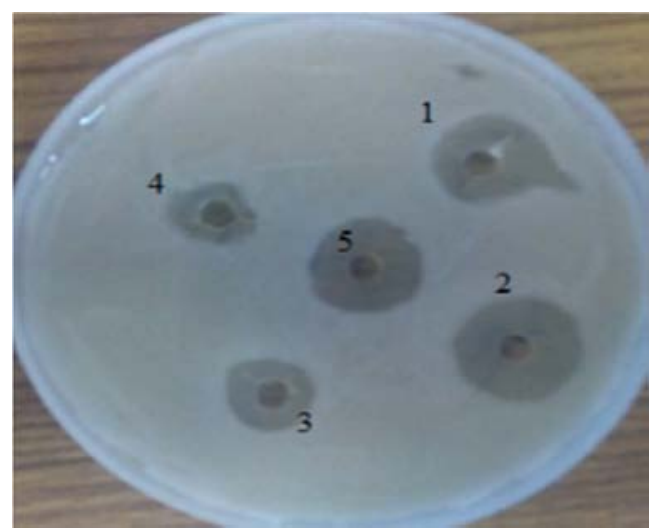

Figure 8. Demonstration of high anti-bacterial activities of organic plant extracts ofSuregada multiflora bark on Escherichia coli KT-1_mdr (accession no. KY769881). (A) Lane 1, Imipenem $10 \mu \mathrm{l}(1 \mathrm{mg} / \mathrm{ml})$, lane 2, Suregada multiflora root extract $20 \mu \mathrm{l}(\sim 10 \mathrm{mg} / \mathrm{ml})$, lane 3, $20 \mu \mathrm{l} \mathrm{NU2} \mathrm{(TLC} \mathrm{purified);}$ lane 4, $20 \mu \mathrm{l} \mathrm{NU3} \mathrm{(TLC} \mathrm{purified)} \mathrm{and} \mathrm{lane} \mathrm{5,} 10 \mu \mathrm{l}(5 \mathrm{mg} / \mathrm{ml}$ Tigicycline).

Discovery and production of plant-derived taxol, quinine, topotecan, epitope and artimisinin are mega projects of pharmaceutical companies. Could we prepare herbal drugs for poor as described in Sanaskrit books Charaka Samhita and Atharva Veda? Use of antibiotics has created an era of AMR and antibiotic-void. However, natural remedies or herbal medicines are bio-compatable and multiple component are there to overcome $m d r$ gene creation. As there are symbiotic relation between plant and soil bacteria, heterogeneous phyto-antibiotics are likely future drugs that are naturally selected. Where as, Labanga (Syzygium aromaticum, flower buds) and Darchini (Cinnamomum zeynalicum, inner bark) extracts have wonderful power to inhibit multidrug-resistant bacteria [8]. Importance of plant derived chemicals to cure multidrug-resistant infections has proved but is not popular yet and Indian Government has acted by making world famous Institutes like CDRI at Lucknow and IICB at Kolkata for research. Our research has established Suregada multiflora (root and bark), Cassia fistula (bark) and Jatropha gossifolia (root) as good source of phyto-chemicals that inhibited superbugs (55). The data supports a view if we cultivate medicinal plants in garden and if we know $10^{\text {th }}$ grade chemistry in mind, then we can make our drug to cure multidrug-resistant infection! In Kolkata city, I have adapted the plantation technology by placing a big clay-pot in the $4^{\text {th }}$ floor roof and such tree is giving 20 gms root every four months enough to cure MDR infection in rats and to cure 100 human drug resistant nail infections. Active ingredients of Suragada multiflora roots however, could be increased to $2.7 \mathrm{x}$ in MS media for 7-14 days using plant tissue culture method (un-published data) $[55,56]$.

\subsection{Phage Therapy}

Bacteriophages are virus that lyse the bacteria and thus has potential against multi-resistance bacteria where most antibiotics fail [57]. April 27, 2018 is the Human Phage Therapy Day, designated to mark 100 years of clinical research launched by Felix d'Herelle, a French microbiologist at Institute Pasteur who is credited with co-discovering bacteriophages with British bacteriologist Frederick Twort. Bacteriophages are ubiquitous viruses and more than $10^{31}$ bacteriophages exist [56]. In phage therapy, lytic mode and Genus and Species specific virus is essential [58]. Bacteriophages present an extensive diversity of shape, size, capsid symmetry and structure with double-stranded (ds) or single-stranded (ss) DNA or RNA genome. Bacteriophage research in India has not get momentum yet as only $1.5 \%$ phages have isolated but in Russia, France, Germany, Georgia and South Korea are far ahead (6-12\% of isolation were reported). The striking principle is bacteria and virus are in symbiosis and lytic mode is hardly maintained in nature favouring lysogenic state [8]. Also if lytic mode is maintained, there are immunological activities and toxin production, those are very bad characters for successful phage therapy [59-61]. Diarrhoea is a great problem in Asia and many children have died from Vibrio cholerae infections and Vibrio specific bacteriophages have characterized extensively and many potential bacteriophages are under clinical trial. Phage Hunters Integrating Research and Education (PHIRE) and the Howard Hughes Medical Institute Science Education Alliance Phage Hunters Advancing Genomics and Evolutionary Science (HHMI SEAPHAGES), have been isolated thousand of bacteriophages using a single host strain, M. smegmatis mc2155.

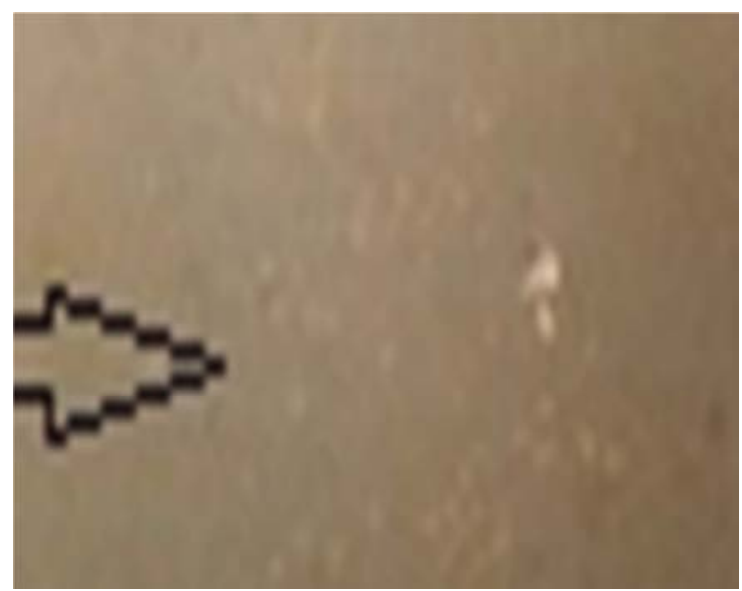

Figure 9. Demonstration of MDR Pseudomonas aeruginosa specific bacteriophages in Kolkata sewage water [8].

In India and other Asian countries the phage research has started and few companies are build for phage therapy research [63]. Bacteriophages were isolated from Klebsiella pneumoniae. Salmonella enterica, Staphylococcus aureus, Acinetobacter baumannii, Vibrio cholerae and Burkholderia pseudomallei [64]. Thus, we expect phage therapy any day will be approved by FDA and MDR bacteria was successfully treated with phage cocktail. We detected bacteriophages in Kolkata sewage but in Ganga River water such lytic phages were poorly detected (figure 9) [8]. 


\subsection{Enzybiotics, A New Hope Against MDR Infections}

The term enzybiotic was coined from two words, enzyme and antibiotic and usually refers as the bacteriophage enzymes that attack the cell wall of bacteria with lyses [65-67]. However, enzybiotic present in bacteria, bacteria infected phages and in body fluids like tears, saliva and animal mucous. We used antibiotics 80 years with success to eradicate pathogenic bacteria like Escherichia, Klebsiella, Salmonella, Mycobacterium, Pseudomonas and Vibrio species until recently antibiotic void has problem. So enzybiotics is a new dimention of superbug control where plant defensins may be used also. Some important enzybiotics are: (a) Lysins. PlyG is Phage- $\gamma$ amidase which can destroy Bacillus anthracis [68] (b) Bacterio ins. Lysostaphinis Streptococcus simulans enzyme that acts as endopeptidase on Staphylocus aureus and many Streptococcei sp. (c) Autolysins. S. equidermis autolysin enzyme lyses $\beta$ (1->4) glycoside bond between $\mathrm{N}$-acetyl glucosamine and $\mathrm{N}$-acetyl muraminic acid of many bacteria (for primary sequence [69]; (d) Lysozymes. Egg white lysozyme is muramidase that destroy peptidoglycans and very effective against Gram $(+)$ bacteria.

The lysins are 453-473aa long extracellular enzymes and have been sequenced from Streptocus suis, Streptocus agalactiae and others (protein ids. WP_061713285, WP_043026720, WP_070043600) with $>50$ mutations showing high heterogeneity among themselves [70]. Autolysins are also much diverged as $S$. aureus enzyme (protein id. AAA99982; accession no. L41499) has only 60\% homology with $8 \%$ gap to other autolysin enzymes (protein id. BAD83399). Genetically recombinant lysins have great potential in curing MDR-bacteria. Pneumococcal LytA autolysin, a potent therapeutic agent in peritonitis-sepsis caused by highly beta-lactamase resistant Streptococcus pneumoniae. Endolysins have a characteristic modular structure with multiple lytic and cell wall-binding domains and can degrade the peptidoglycans with glycosidase, amidase, endopeptidase, or lytic transglycosylase activities and have been shown to be synergistic with other antimicrobials [71]. Endolysin engineering has opened a new era for new therapeutic proteins against many microorganisms that are believed refractory to antibiotics. Enzybiotics is an emerging field of medicinal science with many molecular approaches have undertaken which have patent litigation and many data are hidden from GenBank database now [72]. Novel chimerical endolysins with broad antimicrobial activity against methicillin-resistant Staphylocus aureus was reported. About 1144 enzybiotics along with 216 natural resources (heterogeneous phyto-antibiotics) have been listed in GMEnzy database. phiBIOTICS is another database that represents a solid body of knowledge about all studied therapeutic enzybiotics to date [70]. This database is very important to researchers who are interested in recombinant enzybiotic design and is available online at http://biotechlab.fudan.edu.cn/database/EnzyBase/home.php. Similar report is available in LAMP database from very similar group of scientists [73-76].

\subsection{RNAi Technology, An Emerging Therapeutics Against Antibiotic-Void}

In recent years, there are dramatic exploration of antisense and microRNA research for the control of multidrug-resistance microbes and cancer [77]. The cost of gene medicines is a concern but WHO's order to discover an alternate to antibiotics against high rate superbug spread and calamity is also challenging. It has been shown in many laboratories that gene therapy technologies to express antisense-RNA to specific gene (like peptidoglycan synthesis genes) is a good approach to combat infectious diseases. In India STIs are a great concern due to increase of marriage age and other social problem and a large portion of young people are falling prey to unprotected sex with infected multiple sex-partners. AIDS is a major problem and HIV plus TB is increasing rapidly and anti-retroviral drugs are also costly and very toxic if taken regularly. It appears due to improvement of expression vector and packaging cell lines, introduction of any gene into human muscle and liver is not far away where permanent blockage of superbug using antisense to $m d r$ genes possible [129]. Ren et al. demonstrated by Illumona Deep Sequencing of small RNAs (15-30 nucleotides) from MDR-TB strains and drug-sensitive TB strains that 142 miRNAs were differentially expressed in the MDR MTB strain, compared with the sensitive MTB strain, of which 48 were up-regulated and 94 were down-regulated where as 108 miRNA were only expressed in MDR-TB [78]. In other experiment by Cui J-Y et al found many up-regulated and down-regulated miRNA in TB-patients and finally identified miR-769-5p, miR-320a and miR-22-3p as potential blood-based biomarkers for TB [79]. RNAi technology has a big leap now as FDA has approved (10 August, 2018) RNAi drug (onpattro; 10mg 19base oligonucleotide) against a rare hereditary polyneuropathy disease called transthyretin-mediated amyloidosis (hATTR).

\subsection{Gene Therapy Comes of Age}

Alternate genetic engineering technologies utilizing antisense RNA, ribozyme and siRNA against multidrug-resistant proteins may be an exciting area of research to explore. Looked nucleic FtsZ peptide was disclosed as growth inhibitory to MRSA Staphylocus aureus superbug [80]. Liposomal formulations (10:5:2 OBEHYTOP:oleicacid:vitamin D3) of Mycobacterium antisense RNA of superoxide dismutase (sod A gene; TBS3), catalase-peroxidase (katG gene; TBK1, TBK10), RNA polymerase beta-subunit (rpo B gene; TBR5) and diaminopimelate decarboxylase (lys A gene; TBL5) resulted in statistically significant $(\mathrm{p}<0.05$ in all cases) inhibition (ranges of -51.45 to $-63.00 \%$ at $72 \mathrm{~h} ;-56.75$ to $-67.96 \%$ at $96 \mathrm{~h} ;-51.45$ to $-60.26 \%$ at $150 \mathrm{~h}$ ) compared with phosphorothioate antisense oligonucleotides alone [81]. Crucial roles for the miR-26a/KLF4 and CREB-C/EBP $\beta$ signalling pathways in regulating the survival of Mycobacterium tuberculosis in macrophages was 
demonstrated. Thus, antisense recombinant expression cassette targeting arginase and transcription factor KLF4 may be possible to control survival of MDR TB pathogen in the macrophages.

\subsection{CRISPR-CAS Technology}

Annual CRISPR 2017 conference, held at Montana State University, we are the first to hear about successes of starter companies like Locus Bioscience and Eligo Bioscience using CRISPR-Cas technology to kill the superbug targeting $m d r$ genes [82]. In this method, a short RNA and a short oligonucleotide match could be engineered to CRISPR-complex to cleave mRNA of superbug by endonuclease activity of enzyme. Such attempts are good as expert have anticipated a great horror as we approach 2050 when 10 million deaths mayo cur per year (https://amr-review.org/sites/default/files/AMR\%20Review-2 014). New technologies and newer drugs have failed to control AMR as 450000 new MDR-TB cases in 2017 as declared by WHO recently indicating MDR-void has reached at an astonishing high peak. Thus, gene targeting technology has welcome even it has many obstacle like mutation due to recombination among plasmid DNA molecules with chromosomal DNA.

\subsection{Metal Nanotechnology to Control MDR Spread}

Metal nano-particles alone or in combination with bioactive plant extracts or antibiotic compounds have represented promising candidates in the drug delivery applications because of their dimensions, bio-applicability, biocompatibility and controlled drug release. Most importantly such applications are cost effective and environmental compatible and bactericidal [83]. Most published nano-particles today are silver and gold nanoparticles [84]. Silver (Ag) is a transition metal element having atomic number- $47\left(1 \mathrm{~s}_{2} 2 \mathrm{~s}_{2} 2 \mathrm{p}_{6} 3 \mathrm{~s}_{2} 3 \mathrm{p}_{6} 3 \mathrm{~d}_{10} 4 \mathrm{~s}_{2} 4 \mathrm{p}_{6} 4 \mathrm{~d}_{10} 5 \mathrm{~s}\right)$ and atomic mass-107.87 where as gold $(\mathrm{Au})$ has an atomic number-79 (-Ag. $\left.5 \mathrm{~s}_{2} 5 \mathrm{p}_{6} 5 \mathrm{~d}_{10} 6 \mathrm{~s}\right)$ and atomic mass 170.23 . Inert gas condensation or co-condensation techniques are used where evaporation of metal into an inert atmosphere with the subsequent cooling for the nucleation and growth of the nanoparticles are done. For the biosynthesis silver/gold nano-particles, $1.5 \mathrm{ml}$ of plant extract was mixed with $30 \mathrm{ml}$ of $1 \mathrm{mM} \mathrm{AgNO}$ or $1 \mathrm{mM} \mathrm{HAuCl} 2$ solution and was incubated at $28^{\circ} \mathrm{C}$ for $24 \mathrm{hrs}$ until colourless silver nitrate solution turned brown colour or pale yellowish $\mathrm{HAuCl}_{2}$. The mixture was centrifuged at $6000 \mathrm{rpm}$ for $10 \mathrm{~min}$ and the pellet was re-suspended in sterilized double distilled water and then sprayed on glass slide to make thin film. The thin film was kept in hot air oven to dry and then the thin film was used for the TEM/SEM analysis. The antibacterial efficiency of the nano-particles was determined by introducing the particles into a media containing bacteria in vitro. The nanoparticles were found to be completely cytotoxic to bacteria like Escherichia coli and Pseudomonas aeruginosa for surface concentrations as low as $8 \mu \mathrm{g}$ of $\mathrm{Ag} / \mathrm{cm} 2$. Such biogenic nano-particles however, were studied by absorption spectroscopy using SEM, XRD and FTIR analysis [8, 14]. Nano-particles of these groups (Silver and Gold) containing herbicides, antibiotics, and gene medicines have demonstrated as "magic bullets" interacting at the molecular levels on the plant, animal and microorganism cells. Polyvalent gold-DNA conjugates was shown to improve diabetes in mice when delivered into pancreas islates. Gold NPs-22 has shown to decrease the cytotoxicity of $A \beta$ fibrils and $A \beta$-mediated peroxidise activity. Gold nanoparticles has been shown effective in detection and killing of mycobacterium complex in vivo. Lipid and lyposomes are good agent to carry gene medicines and to delivery into animal cells targeting $m d r$ genes of superbugs. Alginate nano-particle was shown to deliver and kill Mycobacterium tuberculosis. Thus, nanotechnology research is very promising in combating multidrug-resistant infections [8].

\subsection{Nanoarriers Gives a Better Hope for Toxic Drug Delivery Controlling Superbugs}

Research indicated that all carbon nanoparticles could inhibit the growth of bacteria by different mechanisms. Graphenes are monolayer carbon linked by $\mathrm{sp} 2$ orbitals and the graphene oxide was prepared from graphite using oxidizing acids. Antibacterial activity of graphite, graphite oxide and graphene oxide have been demonstrated. Bacterial growth arrest by graphenes was thought to be mechanical but fullerenes (C60 Buckminsterfullerene like soccer ball) activate reactive oxygen species or photo catalytic activities that destroy bacteria. Diamond nanoparticles was thought to act as ROS independent oxidative stress. A quantum-dot sensor complex comprised of thrombin DNA aptamer, gold nanoparticle and semiconductor QD, attached to a graphene oxide nano-particles for detection of potassium ( $1 \mathrm{pm}$ to 100 $\mathrm{nm}$ ) were reported recently and such device could be used to detect multidrug-resistant pathogens involving specific $m d r$ genes [86]. DNA is very stable as protected from nuclease and is very biocompatible. Recently, DNA was used as carriers of proteins and drugs to target specific cells like cancer cells as well as bacterial cells. Typical sizes of DNA nanostructures are $100 \times 70 \mathrm{~nm} 2$ for 2D DNA origami and $25 \times 25 \times 25 \mathrm{~nm} 3$ for $3 \mathrm{D}$ DNA origami structures. Liposome nano-carriers are potentially the future of inner ear therapy due to their high drug loading capacity and are very efficient in treating cancer, infectious disease and inflammation [87].

\section{Conclusion}

G-20 Nations and WHO Action Plans are important to reduce antibiotic void and to combat AMR. But other actions may be important against MDR horror: (i) Immediate action plans are needed to stop generation of oral antibiotics derivatives that create more pressure on bacterial metabolism which act as catalysis for new gene creation; (ii) Mandatory use of vitamin complexes is necessary and combination of synbiotics with antibiotics is must to save the human cells from the crisis of metabolosome; (iii) Direct 
coenzymes like NADH, FADH2, THFA and PLP may help patients and will reduce the $m d r$ gene generation and must be supplied to patients during each antibiotic therapy; (iv) MDR-bacteria with 5-15 $m d r$ genes in MDR conjugative plasmids and chromosomes are very frequent now and phage therapy is a new frontier for medicine, (v) Complex bio-molecules made by microbiota like colipan, linoleic acid, p-cresol etc. will be implement in diet of patients and such research will be accelerated to keep human in this Earth for long time and (vi) Phyto-antibiotics in combination with gene medicines (SiRNA, Ribozymes, CRISPR-CAS and others) and drug nano-carriers will be the future effective treatment options. We demand cultivation of medicinal plants every corner of this globe $[5,8]$.

However, last two decades gradual increase of MDR clinical isolates were shown with $>95 \%$ ampicillin and amoxicillin resistant which so far was controlled by synthesis of new derivatives of penicillin like cephalosporin and carbapenem. In 2009, NDM-1 Escherichia coliwas found that was resistant to all class of penicillins including beta-lactamase inhibitors like cavulinate and sulbactam but avibactam [14]. Skin infections by MRSA Staphylocus aureus, PDR nosocomial infections by Pseudomonas aeroginosa and XDR tuberculosis by Mycobacterium tuberculosis WHO_Z are now serious threat to human and alternative approaches should be needed to overcome such crisis [56]. MDR genes (blaTEM, amp, blaNDM, blaOXA, sul1/2, catB3, aacA4, aacC2, aph, aad, $d h f r, a r r 3, \operatorname{str} A / B$, etc) and drug efflux genes (tet $A$, acrAB-TolC, mexAB-oprM, mcr, macAB, nor $A$, mdtA etc) are wide spread in conjugative plasmids and chromosomes of superbug which are also found in rain, sea and river water posing a threat to global peoples $[27,65]$. Thus, our approach to combat multidrug-resistant infections using heterogeneous-phyto antibiotics is a valuable step and we demand conservation and cultivation of medicinal plants in every corner of this Earth to save mankind. Save plants and use as medicine.

\section{Acknowledgements}

I thank Dr. Jayanta Mukhopadhyay, Bose Institute, Kolkata and Dr Tanmoy Samanta, IIT-Mandi, Himachal Pradesh and Dr. Parthapratim Chakravorty, Gope College, Midnapore for various help during the study. Special thanks to Dr J B Medda, Presedent of OAER for funding. Technical assistance from Kousik Poria, aMSc student of Biotechnology, Vidyasagar University is greatly acknowledged. AKC is Associate Professor of Biochemistry at OIST.

\section{References}

[1] Tortora, G. J., B. R. Funke, and C. L. Case. Microbiology: An Introduction. $12^{\text {th }}$ edi. 2016. ISBN: 9780321929150.

[2] Sebstian P. Ayurvedic Medicine. The principles of traditional practice. $1^{\text {st }}$ Edition 2006. Elsevier Press, ISBN: 9780443100901.
[3] Ackerknecht, E. H. A Short History of Medicine. Baltimore, MD. The Johns Hopkins University Press, 1982.

[4] Chakraborty, A. K (2019) Conceptual Drug Discovery and Societal Status may not be Sufficient to Combat Multidrug-Resistant Infections. Pharmaceutical Regulatory Affairs 7, 213. doi: 10. 4172/2167-7689. 1000213.

[5] Chakraborty, A. K., K. Poira., D. Saha., C. Halder., S. Das et al. (2018) Multidrug- Resistant Bacteria with activated and diversified MDR Genes in Kolkata Water: Ganga Action Plan and Heterogeneous Phyto-Antibiotics tackling superbug spread in India. American Journal of Drug Delivery and Therapeutics 5 (1), 1-9.

[6] Maniatis, T., E. F. Fritsch and Sambrook, J (1982) Molecular Cloning-A Laboratory Manual. Cold Spring Harbour Laboratory, 1982. ISBN: 978-0879691363.

[7] Carey, F. A. and R. A. Sundberg. Advanced Organic Chemistry, $1^{\text {st }}$ edition, Springer, 2005. ISBN: 978-0-387-68350-8.

[8] Chakraborty, A. K (2017) Ganga action plan, heterogeneous phyto-antibiotics and phage therapy are the best hope for India tackling superbug spread and control. Indian Journal of Biological Sciences 23, 34-51.

[9] Sigerst, H. E. A History of Medicine: Early Greek, Hindu and Persian Medicine, vol. II, New York, Oxford University Press, 1987. ISBN: 9780195050790.

[10] Chakraborty, A. K (2019) Current status and unusual mechanism of multi-resistance in Mycobacterium tuberculosis. Journal of Health and Medical Informatics 10, 328. DOI: 10. 4172/2157-7420. 1000328.

[11] Chakraborty, A. K (2018) Worldwide spread of MDR bacteria signals to be resident of gut microbiota for vitamins synthesis and heterogeneous phyto-antibiotics may cure MDR infections globally. Biomedical Research 29, 50. doi: 10. 4066/biomedicalresearch-C1-003.

[12] Chakraborty, A. K (2017) Multi-drug resistant bacteria from Kolkata Ganga River with heterogeneous MDR genes have four hallmarks of cancer cells but could be controlled by organic phyto-extracts. Bioc hemistry and Biotechnology Research 5 (1), 11-23.

[13] Sylvia, D. M., P. G. Hartel., J. J. Fuhrmann and D. A. Zuberer. Principle and Application of Soil Microbiology. 2nd ed. Pearson Prentice Hall, 2005.

[14] Chakraborty, A. K (2015) High mode contamination of multi-drug resistant bacteria in Kolkata: mechanism of gene activation and remedy by heterogeneous phyto-antibiotics. Indian Journal of Biotechnology 14, 149-159.

[15] Chakraborty, A. K., G. E. Muneim., S. Pradhan and A. Adhikari (2018) Superbug horror and its relations to antibiotics, probiotics and vitamins. Journal of Pharmaceutical Toxicology1 (1), 8-13.

[16] Thakar, V. J (2010) Historical development of basic concepts of Ayurveda from Veda up to Samhita. Ayu3 (4). 400-402. doi: 10. 4103/0974-8520. 82024 .

[17] Singh, R., S. Hussian., R. Vermaan and P. Sarma (2013) Anti-mycobacterial screening of five Indian medicinal plants and partial purification of active principle from Cassia sophera and Urtica dioica. Asian Pacific Journal of Tropical Medicine $6(5), 366-371$. 
[18] Clayton, J. C., B. A. Hems., F. A. Robinson., R. D. Andrews and R. F. Hunwicke (1944) Preparation of penicillin. Improved method of isolation. Biochemical Journal 38 (5), 452-458.

[19] Abraham, E. P and E. Chain (1940) An enzyme from bacteria able to destroy penicillin. Rev Infectious Diseases 1988; 10, 677-678.

[20] Chakraborty, A. K (2017) MDR genes are created and transmitted in plasmids and chromosomes to keep normal intestinal microbiota alive against high dose antibiotics- A hypothesis. Journal of Molecular Medicine and Clinical Application 2 (1), 109. doi: 10. 16966/2575-0305. 109.

[21] Le Chatelier, E., T. Nielsen., J. Qin., E. Prifti., F. Hildebrand., et al. (2013) Richness of human gut microbiome correlates with metabolic markers. Nature 500, 541-546.

[22] Ram, J. L., A. S. Karim., E. D. Sendler and I. Kato (2011) Strategy for microbiome analysis using $16 \mathrm{~S}$ gene sequence analysis on the Illumina sequencing platform. System Biology and Reproduction Medicine 57 (3), 162-170. doi: 10. 3109/19396368. 2011. 555598 .

[23] Sanger, F., S. Nicklen and A. R. Coulson (1977) DNA sequencing with chainterminating inhibitors. Proceeding of the National Academy of Sciences USA 74, 5463-5467.

[24] Pérez-Cobas, A. E., A. Artacho., H. Knecht., M. L. Ferrús., A. Friedrichs, et al. (2013) Differential effects of antibiotic therapy on the structure and function of human gut microbiota. PLoS One. 8 (11). e80201. doi: 10. 1371/journal. pone. 0080201.

[25] Salyers, A. A., A. Gupta and Y. Wang (2004) Human intestinal bacteria as reservoirs for antibiotic resistance genes. Trends Microbiology 12 (9), 412-416.

[26] Wei, S., M. Morrison and Z. Yu (2013) Bacterial census of poultry intestinal microbiome. Poultry Science92 (3), 671-683. doi: $10.3382 /$ ps. 2012-02822.

[27] Chakraborty, A. K (2018) Superbugs spread and problems of multidrug-resistant infections during surgery. International Journal of Surgery and Invasive Procedures 1 (1), 6-13.

[28] Chakraborty, A. K (2016) Multi-drug resistant genes in bacteria and $21^{\text {st }}$ Century problems associated with antibiotic therapy. Biotechnology: An Indian Journal 12 (12), 113.

[29] Wani, M. C., H. L. Taylor., M. E. Wall., P. Coggon and A. T. McPhail (1971) Plant antitumor agents. VI. The isolation and structure of taxol, a novel anti-leukemic and anti-tumor agent from Taxus brevifolia. Journal of American Chemical Society 93 (9), 2325-2327.

[30] Paddon, C. J., P. J. Westfall., D. J. Pitera., K. Benjamin., K. Fisher., et al. (2013) High-level semi-synthetic production of the potent antimalarial artemisinin. Nature 49,: 528-532.

[31] Heinig, U., S. Scholz and S. Jennewein (2013) Getting to the bottom of taxol biosynthesis by fungi. Fungal Diversity60, 161-70. doi: 10. 1007/s13225-013-0228-7.

[32] Stierle, A., G. Strobel and D. Stierle (1993) Taxol and taxane production by Taxomyces andreanae, an endophytic fungus of Pacific yew. Science 260 (5105), 214-216. doi: 10. 1126/science. 8097061.

[33] Hsiang, Y. H., R. Hertzberg., S. Hecht and L. F. Liu (1985) Camptothecin induces protein-linked DNA breaks via mammalian DNA topoisomerase I. Journal of Biological Chemistry 260, 14873-14878.
[34] Staines, H. M and S. Krishna. Treatment and prevention of malaria: Antimalarial drug chemistry, action and use. Springer Verlag. 2011; p. 45. ISBN: 9783034604796.

[35] Ro, D. K., E. M. Paradise., M. Ouellet., K. J. Fisher., K. L. Newman., et al. (2006) Production of the antimalarial drug precursor artemisinic acid in engineered yeast. Nature440 (7086), 940-943. doi: 10. 1038/nature04640.

[36] Woodward, Rand W. Doering (1944) The Total Synthesis of Quinine. Journal of American Chemical Soc iety66, 849.

[37] Lévesque, F and P. H. Seeberger (2012) Continuous-Flow synthesis of the anti-malaria drug artemisinin. Angewandte Chemie (International Edition) 51 (7), 1706-1709. doi: 10. 1002/anie. 201107446.

[38] Handa, S. S., S. P. S. Khanuja., G. Longo and D. D. Rakesh (2008) Extraction Technologies for medicinal and aromatic plants, $\left(1^{\text {st }}\right.$ edn $)$, no. 66. 2008. Italy: United Nations Industrial Development Organization and the International Centre for Science and High Technology.

[39] Guo, N., Y. W. Jiang., P. Kou., Z. M. Liu., T. Efferth., et al (2019) Application of integrative cloud point extraction and concentration for the analysis of polyphenols and alkaloids in mulberry leaves. Journal of Pharmaceutical and Biomedical Analysis. 167, 132-139. doi: 10. 1016/j. jpba. 2019. 02. 002.

[40] Vongsak, B., P. Sithisarn., S. S. Mangmool., S. Thongpraditchote., Y. Wongkrajang., et al. (2013) Maximizing total phenolics, total flavonoids contents and antioxidant activity of Moringaoleifera leaf extract by the appropriate extraction method. Industrial Crops and Products $44,566-571$.

[41] Dhooghe, L., K. Mesia., E. Kohtala., L. Tona., L. Pieters., et al. (2008) Development and validation of an HPLC-method for the determination of alkaloids in the stem bark extract of Nauclea pobeguinii. Talanta76 (2), 462-468. doi: 10. 1016/j. talanta. 2008. 03. 036.

[42] Kandiah, M and P. L. Urban (2013) Advances in ultrasensitive mass spectrometry of organic molecules. Chemical Society Reviews 42 (12), 5299-5322. doi: 10. 1039/c3cs35389c.

[43] Sobott, F. Biological Mass Spectrometry. Boc a Raton: CRC Press-I LLC, 2014. ISBN: 978-1439895276.

[44] Pavia, D. L., G. M. Lampman., G. S. Kriz and J. R. Introduction to Spectroscopy. $5^{\text {th }}$ edi. Chapter 6, Pp. 290-347, 2013. Cengage Learning. ISBN: 978-1-285-46012-3.

[45] Dyer, J. R. Applications of absorption spectroscopy of organic compounds. Eastern Economy Edition, Chapter 3, Pp. 22-57, 2015. PHI Learning Private Limited. ISBN: 978-81-203-0252-5.

[46] Sastri, B. N. Ed. The Wealth of India, Raw Materials, Vol. IV, 1956, CSIR, New Delhi, India.

[47] Cowan, M. M (1999) Plant products as antimicrobial agents. Clinical Microbiology Review 12, 564-582.

[48] Laxminarayana, R (2014) Antibiotic effectiveness: Balancing conservation against innovation. Science 345, 1299-3101.

[49] Noumedem, J. A., M. Mihasan., S. T. Lacmata., M. Stefan., J. R. Kuiate., et al. (2013) Antibacterial activities of the methanol extracts of ten Cameroonian vegetables against Gram-negative multidrug-resistant bacteria. BMC Complementary and Alternative Medicine 13, 26-34. 
[50] Daglia, M (2011) Polyphenols as antimicrobial agents. Current Opinion on Biotechnology23: 174-181.

[51] Chaieb, K., H. Hajlaoui, T. Zmantar., A. B. Kahla-Nakbi. M. Rouabhia., et al. (2007) The chemical composition and biological activity of clove essential oil, Eugenia caryophyllata (Syzygiumaromaticum L. Myrtaceae): a short review. Phytotherapy Research 21 (6), 501-506.

[52] Dubey, R. C., A. Rana and R. K. Shukla (2005) Antibacterial activity of essential oils of some medicinal plants against certain human pathogens. Indian Drugs 42, 443-446.

[53] Elumalai, S., R. Kesavan., S. Ramganesh., V. Prakasamand., R. Murugasen (2010) Comparative study on anti-microbial activities of bark oil extract from Cinnamomum cassia and Cinnamomum zeylanicum. Bioscience and Biotechnology Research Asia 7, 251-258.

[54] Lee, J. H., S. Cho., H. D. Paik., C. W. Choi., K. T. Nam., et al. (2014) Investigation on antibacterial and antioxidant activities, phenolic and flavonoid contents of some Thai edible plants as an alternative for antibiotics. Asian-Australasian Journal of Animal Sciences. 27 (10), 1461-1468.

[55] Chakraborty, A. K. Heterogeneous Phyto-Antibiotics will be Future Drugs against Superbugs. Proceeding of the 106th Indian Science Congress, Medicinal Sciences Section, Jan. 2-7, 2019. Lovely Professional University, India.

[56] Chakraborty, A. K., A. Khatoon., M. Maity., S. K. Nandi and U. Maity. Screening of some clinically important anti-bacterial phyto-extracts as described in Chiranjib Bonoushadhi targeting Kolkata superbugs. In: "Health, Nutrition and Hygiene: The Dynamics of Social Ecology in India" (edi. Sinha, Patsa, Das, Samanta), Chapter 30, pp. 260-278, 2016. ISBN: 978-81-930138-1-6.

[57] Kutter, E. M., S. J. Kuhland and S. T. Abedon (2015) Re-establishing a place for phage therapy in western medicine. Future Microbiology 10, 685-588.

[58] Jensen, K. C., B. B. Hair., T. M. Wienclaw., M. H. Murd k., J. B. Hatch., et al. (2015) Isolation and host range of bacteriophage with lytic activity against methicillin-resistant Staphyl cus aureus and potential use as a fomite decontaminant. PLoS One10 (7), e0131714.

[59] Dalmasso, M., R. Strain., H. Neve., C. M. Franz., F. J. Cousin., et al. (2016) Three new Escherichia coli phages from the human gut show promising potential for Phage Therapy. PLoS One 11 (6), e0156773. doi: 10. 1371/journal. pone. 0156773 .

[60] Yu, Y. -P., T. Gong., G. Jost., W. -H. Liu., D. -Z. Ye and Z. -H. Luo (2013) Isolation and characterization of five lytic bacteriophages infecting a Vibrio strain closely related to Vibrio owensii. FEMS Microbioogyl Letters348 (2), 112-119.

[61] Yang, H., L. Liang., S. Lin andS. Jia (2010) Isolation and characterization of a virulent bacteriophage $\mathrm{AB} 1$ of Acinetobacterbaumannii. BMC Microbiology10 (1), 131. doi: 10. 1186/1471-2180-10-131.

[62] Carey-Smith, G. V., C. Billington., A. J. Cornelius., J. A. Hudson andJ. A. Heinemann (2006) Isolation and characterization of bacteriophages infecting Salmonella spp. FEMS Microbiology Letters258 (2), 182-186.

[63] Schooley, R. T., B. Biswas., J. J. Gill., A. Hernandez-Morales., J. Lancaster., L. Lessor., et al. (2017) Development and use of personalized bacteriophage-based therapeutic coc ktails to treat a patient with a disseminated resistant Acinetobacterbaumannii infection. Antimicrobial Agents and Chemotherapy 61 (10). pii: e00954-17. doi: 10. 1128/AAC. 00954-17.

[64] Chakraborty, A. K (2017) Enzybiotics, A new class of enzyme antimicrobials targeted against multidrug-resistant superbugs. Novel Approach of Drug Design and Development 2 (4), 555592 .

[65] Chakraborty, A. K (2017) Diversified mdr genes in bacterial plasmids and chromosomes inactivate hundred drugs with huge superbug spread in sea, river and rain water. Journal of Pharmacovigilance 5 (Suppl 4), 29. doi: 10. 417/2329-6887-C1-029.

[66] Rodríguez-Cerrato, V., P. García., L. Huelves., E. García., G. Del Prado., M. Gracia., et al. (2007) Pneumococcal LytA autolysin, a potent therapeutic agent in peritonitis-sepsis caused by highly beta-lactamase resistant Streptococcus pneumoniae. Antimicrobial Agents and Chemotherapy 51 (9), 3371-3373.

[67] Yang, H., Y. Zhang., J. Yu., Y. Huang., X. E. Zhang., et al. (2014) A novel chimeric lysine with high antimicrobial activity against methicillin-resistant Staphylococ cus aureus in vitro and in vivo. Antimicrobial Agents Chemotherapy 58 (1), 536-542.

[68] Fernandes, S., D. Proença., C. Cantante., F. A. Silva., C. Leandro., et al. (2012) Novel chimerical endolysins with broad antimicrobial activity against methicillin-resistant Staphylococcus aureus. Microbial drug resistance 18, 333-343. doi: 10. 1089/mdr. 2012. 0025.

[69] Wu, H., J. Huang., H. Lu., G. Li and Q. Huang (2014) GMEnzy: A genetically modified enzymatic database. PLoS One 9 (8), e103687.

[70] Rodríguez-Rubio, L., D. Gutiérrez., D. M. Donovan., B. Martínez., A. Rodríguez., et al. (2016) Phage lytic proteins: biotechnological applications beyond clinical antimicrobials. Critical Review in Biotechnology 36 (3), 542-552. doi: 10. 3109/07388551. 2014. 993587.

[71] Borysowaski, J and A. Gorski. Enzybiotics and their potential application in medicine. In: Villa TG, Veiga-Crespo P., editors. Enzybiotics: antibiotic enzymes as drugs and therapeutics, First edi. Pp. 199-218, 2009. New Jersy: John Wiley \& Sons Inc. Publication. ISBN: 9780470376553.

[72] Hojckova, K., M. Stano and L. Klucar (2013) phiBIOTICS: catalogue of therapeutic enzybiotics, relevant research studies and practical applications. BMC Microbiology 13, 53. doi: 10.1186/1471-2180-13-53

[73] Zhao, X., H. Wu., H. Lu., G. Li and Q. Huang (2013) LAMP: A Database Linking Antimicrobial Peptides. PLoS One; 8 (6), e66557. doi: 10. 1371/journal. pone. 0066557.

[74] Rashel, M., J. Uchiyama., T. Ujihara., Y. Uehara., S. Kuramoto., et al. (2007) Efficent elimination of multidrug-resistant S. aureus by cloned Lysin derived from bacteriophage Phi MR11. Journal of Infecious Diseases19 (8), $1237-1247$

[75] Becker, S. C., F. J. Foster andD. M. Donovan (2008) ThephageK lytic enzyme LysK and lysostaphin act synergistically to kill MRSA. FEMS Microbiology Letters 287 (2), 185-191. 
[76] Baroni, D and P. Arrigo (2014) MicroRNA target and gene validation in viruses and bacteria. Methods in Molecular Biology 1107, 223-231. doi: 10. 1007/978-1-62703-748-8_13.

[77] Ren, N., G. Gao., Y. Sun., L. Zhang., H. Wang., et al. (2015) MicroRNA signatures from multidrug resistant Mycobacterium tuberculosis. Molecular Medicine Reports 12 (5), 6561-6567. doi: 10. 3892/mmr. 2015. 4262.

[78] Cui, J. Y., H. W. Liang., X. L. Pan., D. Li., N. Jiao., et al. (2017) Characterization of a novel panel of plasma microRNAs that discriminates between Mycobacterium tuberculosis infection and healthy individuals. PLoS One12 (9), e0184113. doi: 10. 1371/journal. pone. 0184113.

[79] Meng, J., F. Da., X. Ma., N. Wang., Y. Wang., et al. (2015) Antisense growth inhibition of methicillin-resistant Staphylococcus aureus by loc ked nucleic acid conjugated with cell penetrating peptide as a novel FtsZ inhibitor. Antimicrobial Agents Chemotherapy59 (2), 914-922.

[80] Das, A. R., N. Dattagupta., C. N. Sridhar., W. K. Wu (2003) A novel thiocationic liposomal formulation of antisense oligonucleotides with activity against Mycobacterium tuberculosis. Scandinavian Journal of Infectious Diseases 35 (3), 168-174.

[81] Yu, K. R., H. Natanson and C. E. Dunbar (2016) Gene Editing of human hematopoietic stem and progenitor cells: promise and potential hurdles. Human Gene Therapy 27 (10), 729-740. doi: 10. 1089/hum. 2016. 107.

[82] Chakraborty, A. K., M. A. Zink and C. P. Hodgson (1995) Expression of VL30 vectors in human cells that are targets for gene therapy. Biohemical Biophysical Research Communication 209 (2), 677-683.

[83] Baker, C., A. Pradhan., L. Pakstis., D. J. Pochan and S. I. Shah (2005) Synthesis and antibacterial properties of silver nanoparticles. Journal of Nanoscience and Nanotechnology5 (2), 244-249.

[84] Chakraborty, A. K. Nucleic-Acids Based Nanocarriers, in "Nanocarriers for Drug Delivery". eds. Mahapatra et al. 2018; Chapter-5; Pp. 155-172, Elsevier Press, Amsterdam. ISBN: 978012814

[85] Chakraborty, A. K., S. Pradhan., S. Das., M. Maity., S. Sahoo., et al. (2019) Complexity of OXA beta-lactamases involved in multi-resistance. British Journal of Bio-Medical Research 3 (1): 772-798.

[86] Pelgrift, R. Y and A. J. Friedman (2013) Nanotechnology as a therapeutic tool to combat microbial resistance. Advanced Drug Delivery Review 65 (13), 1803-1815. 